\title{
具有光热性能的碳龙配合物材料
}

\author{
吴 凡 ${ }^{a}$ 黄文超 ${ }^{c}$ 卓凯玥 $b$ 华煜晖 $b$ 林剑锋 ${ }^{b}$ \\ 何国梅 $*, a$ 陈江溪 ${ }^{a}$ 聂立铭 $*, c$ 夏海平 $*, b$ \\ ( ${ }^{a}$ 厦门大学材料学院材料科学与工程系 厦门 361005) \\ $\left(^{b}\right.$ 厦门大学化学化工学院化学系 厦门 361005)
}

( ${ }^{c}$ 厦门大学公共卫生学院分子影像暨转化医学研究中心分子疫苗学和分子诊断学国家重点实验室 厦门 361102)

\begin{abstract}
摘要 金属有机化合物很少作为光热材料. 报道一系列碳龙配合物的合成及其光热性能, 将 $\mathrm{OsCl}_{2}\left(\mathrm{PPh}_{3}\right)_{3}$ 与有机多炔 碳链反应获得金属杂戊搭炔, 再与末端炔烃发生 $[2+2]$ 环加成反应得到此类碳龙配合物一一锇杂戊搭烯并环丁二烯. 这些共轭的金属杂环化合物在紫外-可见区具有宽吸收并表现出优异的光热性能, 有望成为一类新型的光热材料. 关键词 金属有机化合物; 金属杂环; 光热效应
\end{abstract}

\section{Carbolong Complexes as Photothermal Materials}

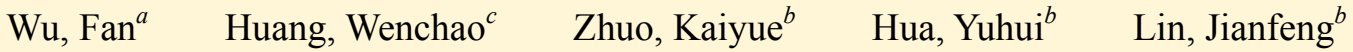
He, Guomei*,a
Chen, Jiangxi ${ }^{a}$
Nie, Liming*,c
Xia, Haiping ${ }^{*, b}$ \\ ( ${ }^{a}$ Department of Materials Science and Engineering, College of Materials, Xiamen University, Xiamen 361005) \\ $\left({ }^{b}\right.$ Department of Chemistry, College of Chemistry and Chemical Engineering, Xiamen University, Xiamen 361005) \\ ( ${ }^{c}$ State Key Laboratory of Molecular Vaccinology and Molecular Diagnosis, Center for Molecular Imaging and Translational \\ Medicine, School of Public Health, Xiamen University, Xiamen 361102)
}

\begin{abstract}
A series of photothermal cyclobutaosmapentalenes with conjugated groups attached to the metallacycle were synthesized from the reaction of $\mathrm{OsCl}_{2}\left(\mathrm{PPh}_{3}\right)_{3}$ with an organic multiyne and $\mathrm{PPh}_{3}$, followed by a [2+2] cycloaddition with terminal alkynes. These highly conjugated metallacycles showed broad UV-Vis absorption and good photothermal efficiency. These easily synthesized metallacycles represent a type of new photothermal material.

Keywords organometallics; metallacycle; photothermal
\end{abstract}

Metallacycles ${ }^{[1 \sim 5]}$ containing a metal and a conjugated carbon-chain have attracted more and more attention as novel materials, because they could show both properties of the metal fragment and the organic framework. For instance, a series of planar Craig-type Möbius ${ }^{[6]}$ metallacylces, called "carbolong" complexes, ${ }^{[6 s \sim 6 t, 7]}$ have been reported. These "carbolong" complexes displayed various properties, including aggregation enhanced emission (AEE) ${ }^{[8]}$ single-molecular conductivity ${ }^{[9]}$ photothermal conversion, ${ }^{[10]}$ and photoacoustic response. ${ }^{[10 a]}$

Among these interesting properties, the photothermal conversion is one of the most important properties for carbolong complexes. For example, the photothermal efficiency of complex 1 (Figure 1a) is about equal to the performance of Au nanoparticles, ${ }^{[11]}$ which are normally used for surface or physical modifications. ${ }^{[12]}$ For comparison, complex 1 can be easily chemically modified and bonded to functional frameworks, obtaining functional macromolecules or micelles (Figure 1b). ${ }^{[10 b \sim 10 d]}$ Interestingly, the substituents in complex 1 have considerable influence on its absorption and photophysical properties. This effect has also been observed in complex 2 (Figure 1a), which shows a broad absorption covering the range of $700 \sim 900 \mathrm{~nm}$ owing to the $J$-aggregates in the substituent. ${ }^{[10 c]}$

Recently, our group discovered a simple way to prepare "carbolong" complexes in a one-pot reaction ${ }^{[13,14]}$ by treatment of multiyne ("carbolong") with simple organometallic starting material. This one-pot "carbolong" method feasibly offered us a means of introducing more substituent groups into these matallacycles using different

\footnotetext{
* Corresponding authors. E-mail: gmhe@xmu.edu.cn; nielm@xmu.edu.cn; hpxia@xmu.edu.cn

Received January 28, 2019; revised March 13, 2019; published online March 21, 2019.

Project supported by the National Natural Science Foundation of China (Nos. 21302158, U1705254, 21490573).

国家自然科学基金(Nos. 21302158, U1705254, 21490573)资助项目.
} 
multiynes.

Inspired by these founding, we realize that the photothermal behavior of complexes such as $3^{[10 \mathrm{a}]}$ can be improved by modifying their substituents. In this work, we introduced different aromatic groups into 3 via the one-pot "carbolong" method and obtained a series of new photothermal cyclobutaosmapentalenes, which could be used as new photothermal materials. These new complexes are easily synthesized and show better photothermal behavior than other complexes such as 3. Moreover, they contained organic functional groups, such as amines or pyridines, which can be used for chemical conjugation or chelation to other functional molecular frameworks or metal fragments.

\section{Results and discussion}

\subsection{Synthesis of new carbolong complexes}

To obtain cyclobutaosmapentalenes with more conjugated groups attached to its metallacyclic moiety, we have developed a new synthetic method based on the one-pot "carbolong" method involving a new multiyne. Thus, treatment of $\mathrm{OsCl}_{2}\left(\mathrm{PPh}_{3}\right)_{3}(4)$ with the multiyne 5 and $\mathrm{PPh}_{3}$ in dichloromethane under argon at $55{ }^{\circ} \mathrm{C}$ for $6 \mathrm{~h}$ afforded an air stable complex (6) containing a conjugated 3-thiophenyl group in $80 \%$ yield (Scheme 1).
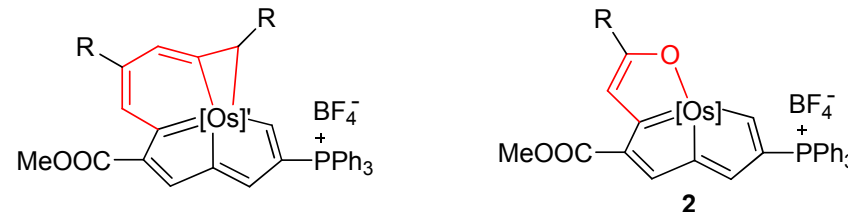

2

1

$\mathrm{R}=$ Phenyl

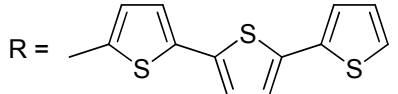$$
{ }_{2}
$$

[Os] $=\mathrm{Os}\left(\mathrm{PPh}_{3}\right)_{2} \mathrm{Cl},[\mathrm{Os}]^{\prime}=\mathrm{Os}\left(\mathrm{PPh}_{3}\right)_{2}$
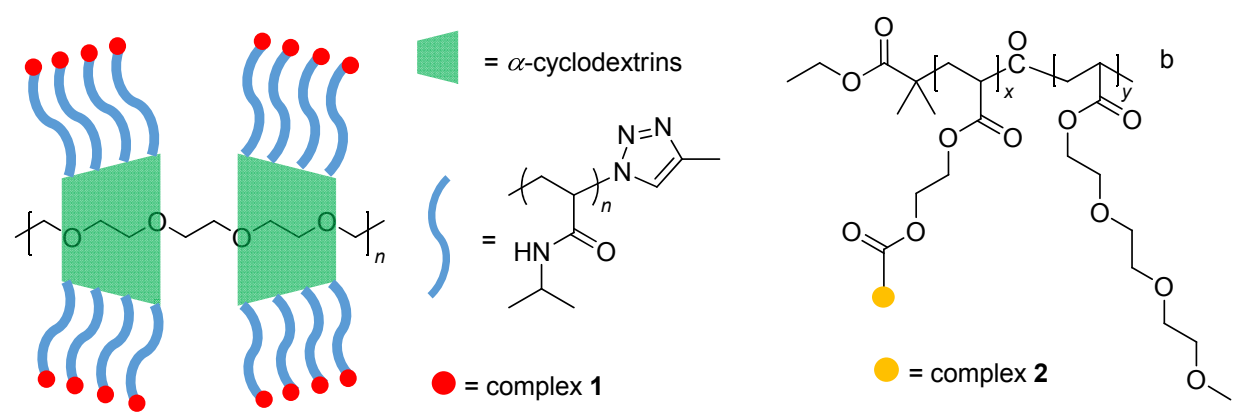

Figure 1 (a) Carbolong complexes $1 \sim 3$ and (b) their polymeric derivatives<smiles>[R]C(O)(C#C)C#CCCCC#C</smiles>

4

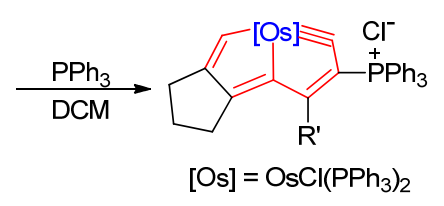

$[\mathrm{Os}]=$<smiles>[R]=[Y9]([H])([H])c1ccc(-c2ccsc2)cc1</smiles>

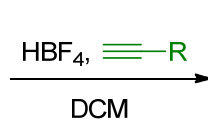

DCM

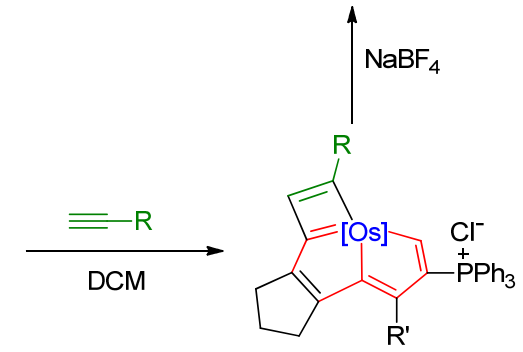

$8 \sim 11$
8: $R=-$

9: $\mathrm{R}=-\prod_{/ / 1}$

10: $\mathrm{R}=-\left\{-\mathrm{NH}_{2}\right.$

11: $\mathrm{R}=-\{-\mathrm{CN}$

Scheme 1 Synthesis of complexes $\mathbf{6} \sim \mathbf{1 2}$ 
Complex 6 was identified by its nuclear magnetic resonance (NMR) and high-resolution mass spectrometry (HRMS) data. Similar to reported osmapentalynes, ${ }^{[13]}$ complex 6 showed two resonances in its ${ }^{31} \mathrm{P}\left\{{ }^{1} \mathrm{H}\right\}$ NMR spectrum at $\delta 5.68\left(\mathrm{t}, J_{\mathrm{PP}}=5.7 \mathrm{~Hz}, \mathrm{CPPh}_{3}\right)$ and $3.76(\mathrm{br}$, $\left.\mathrm{Os} P \mathrm{Ph}_{3}\right)$. In addition, a metal-carbyne [C(1)] signal was observed at $\delta 318.2$ in its ${ }^{13} \mathrm{C}\left\{{ }^{1} \mathrm{H}\right\}$ NMR spectrum. The signals for other carbons $[\mathrm{C}(2), \mathrm{C}(3), \mathrm{C}(4), \mathrm{C}(5), \mathrm{C}(6)$, and $\mathrm{C}(7)]$ in the metallacycle were located at $\delta 125.7,163.9$, 168.8, 181.0, 176.6 and 214.9, respectively. In ${ }^{1} \mathrm{H}$ NMR spectrum, the signal of $\mathrm{H}^{7}$ was located at $\delta 13.17$. The aliphatic ring showed the signals at $\delta 1.12,1.71$ and 2.50 for $\mathrm{H}(8), \mathrm{H}(9)$ and $\mathrm{H}(10)$, respectively. These values were similar to the corresponding signals for reported osmapentalynes, ${ }^{[13]}$ showing that they have a similar metallacyclic structure. The molecular formula of complex 6 was also confirmed by its HRMS data, which has a peak at $\mathrm{m} / \mathrm{z}$ 1299.2886.

Complex 6 was then efficiently converted to the metallapentalyne (7) in the presence of acid $(\mathrm{HCl})$. The shift of the metal-carbyne bond in the presence of $\mathrm{HBF}_{4}$ was known and driven thermodynamically and proceeded via the 16e metallapentalene intermediate. ${ }^{[8]}$ The structure of metallapentalyne 7 was also assigned on the basis of its NMR and HRMS data. For example, complex 7 shows two identical resonances at $\delta 13.63\left(\mathrm{br}, \mathrm{CPPh}_{3}\right)$ and $9.13(\mathrm{~d}$, $\left.J_{\mathrm{PP}}=5.0 \mathrm{~Hz}, \mathrm{Os} P \mathrm{Ph}_{3}\right)$ in its ${ }^{31} \mathrm{P}\left\{{ }^{1} \mathrm{H}\right\}$ NMR spectrum, which is similar to those for other reported osmapentalynes. ${ }^{[8]}$ In ${ }^{13} \mathrm{C}\left\{{ }^{1} \mathrm{H}\right\}$ NMR spectrum, the carbyne $\left(\mathrm{C}^{7}\right)$ signal of complex 7 is located at $\delta 320.3$. The characteristic signal of $\mathrm{H} 1$ in ${ }^{1} \mathrm{H}$ NMR spectrum is at $\delta 13.48$. Moreover, the molecular formula of complex 7 is also supported by its HRMS data $(m / z=1299.2910)$. It is noteworthy that metallapentalyne 7 , in contrast to complex $\mathbf{6}$, can be slowly oxidized in air and should be stored under an inert atmosphere.

When the metallapentalyne 7 was treated with different terminal aryl alkynes, including 3-ethynylthiophene, 4-ethynylpyridine, 4-ethynylaniline, and 4-ethynylbenzonitrile, the $[2+2]$ cycloaddition reaction ${ }^{[10 a]}$ proceeded smoothly to afford the designed cyclobutaosmapentalenes $\mathbf{8} \sim \mathbf{1 1}$, respectively. Complexes $\mathbf{8} \sim \mathbf{1 1}$ were characterized by NMR spectroscopy, HRMS, and elemental analysis (EA). In particular, the characteristic $\mathrm{H}^{1}$ signal of complex 8 appears at $\delta 13.62$ in the ${ }^{1} \mathrm{H} \mathrm{NMR}$, and is thus similar to that of 3. In the ${ }^{31} \mathrm{P}\left\{{ }^{1} \mathrm{H}\right\} \mathrm{NMR}$ spectrum, the signals at $\delta$ -16.13 and 10.21 are assigned for $\mathrm{OsPPh}_{3}$ and $\mathrm{CPPh}_{3}$. The characteristic peak of C(1) can be observed at $\delta 234.6$. The molecular formula of complex $\mathbf{8}$ is supported by its HRMS data $(m / z=1407.2821)$. Complexes $9 \sim 11$ have NMR spectra similar to that of complex $\mathbf{8}$, supporting the view that they have a similar metallacyclic substructure.

To further confirm the structure of complex $\mathbf{8}$, we successfully grew and analyzed crystallographically a high quality single crystal of complex $\mathbf{1 2}$, which was produced by the anion exchange reaction of complex 8 with $\mathrm{NaBF}_{4}$. As shown in Figure 2, the complex 12 contains a near- planar metal-bridged tricyclic structure, as reflected by the small mean deviation from the least-squares plane $(0.0054$ $\mathrm{nm})$. The osmium atom is coordinated with seven other atoms, including four carbon atoms [C(1), C(4), C(7) and $\mathrm{C}(9)$, one chlorine atom and two phosphorus atoms, and has a pentagonal bipyramid configuration with an 18 electron center. This is identical with $3^{[10 a]}$ The thiophenyl group on $\mathrm{C}(9)$ of $\mathbf{1 2}$ is slightly rotated from the metallacycle, while the phenyl group on $\mathrm{C}(3)$ is almost vertical. The osmium-carbon bond lengths of Os(1)-C(1) (0.2070 nm), Os(1) - C(4) (0.2163 nm), and Os(1)-C(7) (0.2071 nm) are within the range of reported $\mathrm{Os}-\mathrm{C}$ bond lengths in osmapentalenes $(0.1926 \sim 0.2175 \mathrm{~nm}) .{ }^{[10 \mathrm{a}]}$ The carbon-carbon bond lengths in this metallacycle $(0.1360 \sim$ $0.1437 \mathrm{~nm}$ ) are similar to the $\mathrm{C}-\mathrm{C}$ bond length in benzene $(0.1396 \mathrm{~nm})$. Thus, the structural features indicated that complexes $\mathbf{1 2}$ and $\mathbf{8}$ have a metallacyclic structure similar to that of 3, except that they have two conjugated groups on the metallacycle. Complex 12 can be produced directly from complex $\mathbf{6}$ and the alkyne $(\mathrm{HC} \equiv \mathrm{CR}, \mathrm{R}=$ 3-thiophenyl) in the presence of $\mathrm{HBF}_{4}$. Complexes $\mathbf{8} \sim \mathbf{1 2}$ are air stable and can be stored as solids in air at room temperature for several weeks.

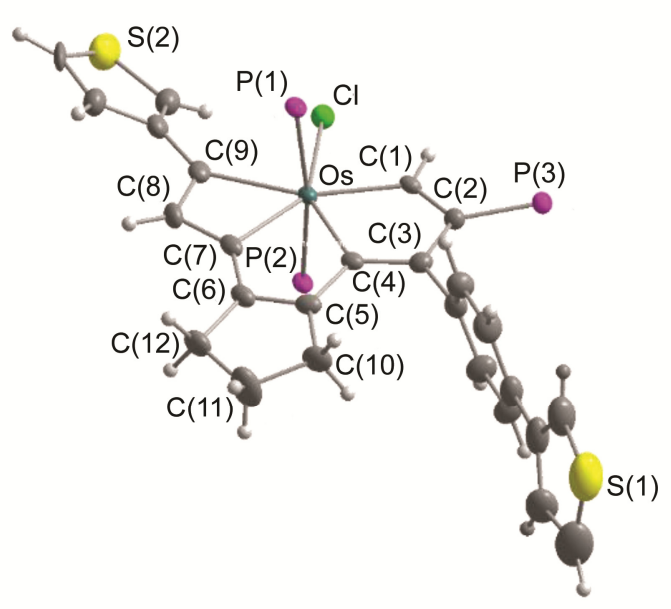

Figure 2 X-ray structure of the cation of complex 12 ellipsoids at the $50 \%$ probability level, phenyl groups in $\mathrm{PPh}_{3}$ moieties were omitted for clarity

\subsection{UV-Vis-NIR absorption spectra}

These new complexes exhibit broad absorption bands in UV-Vis-NIR absorptions (Figure 3). In particular, the maximum absorptions of complexes $\mathbf{8}$ and $\mathbf{1 0}$ at $\lambda 714$ and $723 \mathrm{~nm}$ are red-shifted compared to those of complexes $\mathbf{1}$, 9 and 11, indicating that they have better delocalized ring structures. This result is understandable, because 3-thiophenyl (8) and 4-aminophenyl (10) groups are electron donors compared to the 4-pyridinyl (9) or 4-cyanophenyl (11) groups. The maximum absorptions of complexes 9 and 11 are at 682 and $691 \mathrm{~nm}$. Thus, the substituents on cyclobutaosmapentalenes show obviously influence on their absorptions. 


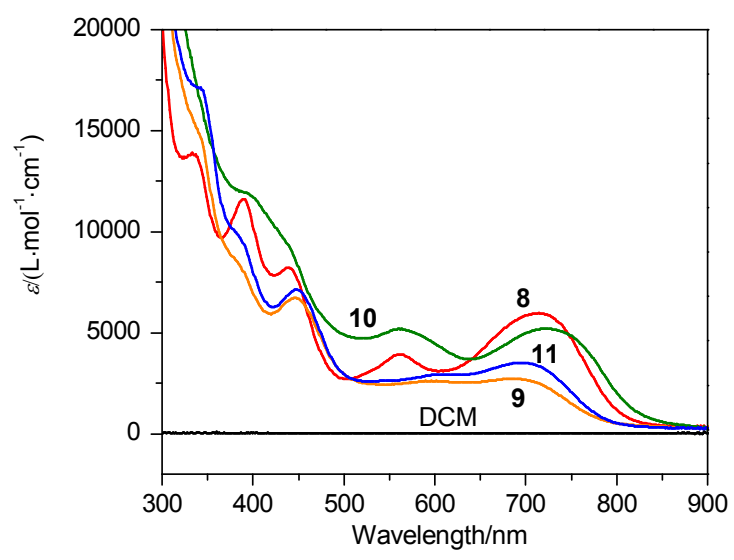

Figure 3 UV-Vis-NIR absorption spectra of complexes $\mathbf{8} \sim \mathbf{1 1}$ $\left(5 \times 10^{-5} \mathrm{~mol} \cdot \mathrm{L}^{-1}\right)$ measured in dichloromethane $(\mathrm{DCM})$ at room temperature

\subsection{Photothermal conversion}

Compared to complexes 3, complexes $\mathbf{8} \sim \mathbf{1 1}$ showed more red-shifted peaks, to $808 \mathrm{~nm}$ in the maximum absorption wavelength. Near-infrared (NIR) light with superior tissue penetration ability ${ }^{[15]}$ has been shown to be a promising low energy light source, which is less harmful. Absorbed by the NIR-absorbing materials, the energy of NIR light can be converted to heat and applied in many areas. ${ }^{[16]}$ Thus, the photothermal conversion of these complexes was investigated to assess their suitability as photothermal materials. As shown in Figure 4a, when the solution containing $0.50 \mathrm{mg} / \mathrm{mL}$ of $\mathbf{1 0}$ was exposed to an NIR laser irradiation at a laser power density of $1.0 \mathrm{~W} / \mathrm{cm}^{2}$, it exhibited significant temperature increase from $28{ }^{\circ} \mathrm{C}$ to $79{ }^{\circ} \mathrm{C}$ within $6 \mathrm{~min}$, indicating very good photothermal properties. For comparison, the solution of complex 8 increased from $28{ }^{\circ} \mathrm{C}$ to $57{ }^{\circ} \mathrm{C}$ within 5 min under the same conditions $\left(0.50 \mathrm{mg} / \mathrm{mL}, 808 \mathrm{~nm}\right.$ laser, $\left.1.0 \mathrm{~W} / \mathrm{cm}^{2}\right)$, while the solution of complex 9 increased from $28{ }^{\circ} \mathrm{C}$ to $47{ }^{\circ} \mathrm{C}$ within $6 \mathrm{~min}$. These results indicate that cyclobutaosmapentalenes $(\mathbf{8} \sim \mathbf{1 1})$ possess better photothermal abilities than 3, due to the red-shifted absorptions. Among these, complex 10 shows the best photothermal conversion efficiency.

Figure $4 \mathrm{~b}$ shows the temperature curves of complex $\mathbf{1 0}$ in different concentrations irradiated by an $808 \mathrm{~nm}$ laser at a power density of $1.0 \mathrm{~W} / \mathrm{cm}^{2}$ in water-ethanol solution $(90$ vot $\%)$. When the complex 10 at $0.25 \mathrm{mg} / \mathrm{mL}$ was irradiated by a NIR laser, its temperature increased from $26{ }^{\circ} \mathrm{C}$ to $58{ }^{\circ} \mathrm{C}$ within $5 \mathrm{~min}$, indicating the linear relationship of its concentration and photothermal conversion ability.

To further investigate the photostability of complex 10, we performed 5 laser on-off cycles under identical conditions $\left(0.25 \mathrm{mg} \cdot \mathrm{mL}^{-1}\right.$, irradiated by $1.0 \mathrm{~W} / \mathrm{cm}^{2}$ laser in water-ethanol solution, 90 vot $\%)$. No obvious change was observed during five cycles (Figure 4c). The final temperature remained stable at every cycle, indicating its good stability under $808 \mathrm{~nm}$ laser irradiation. Thus, complex $\mathbf{1 0}$ represents a new type of photothermal molecule with an
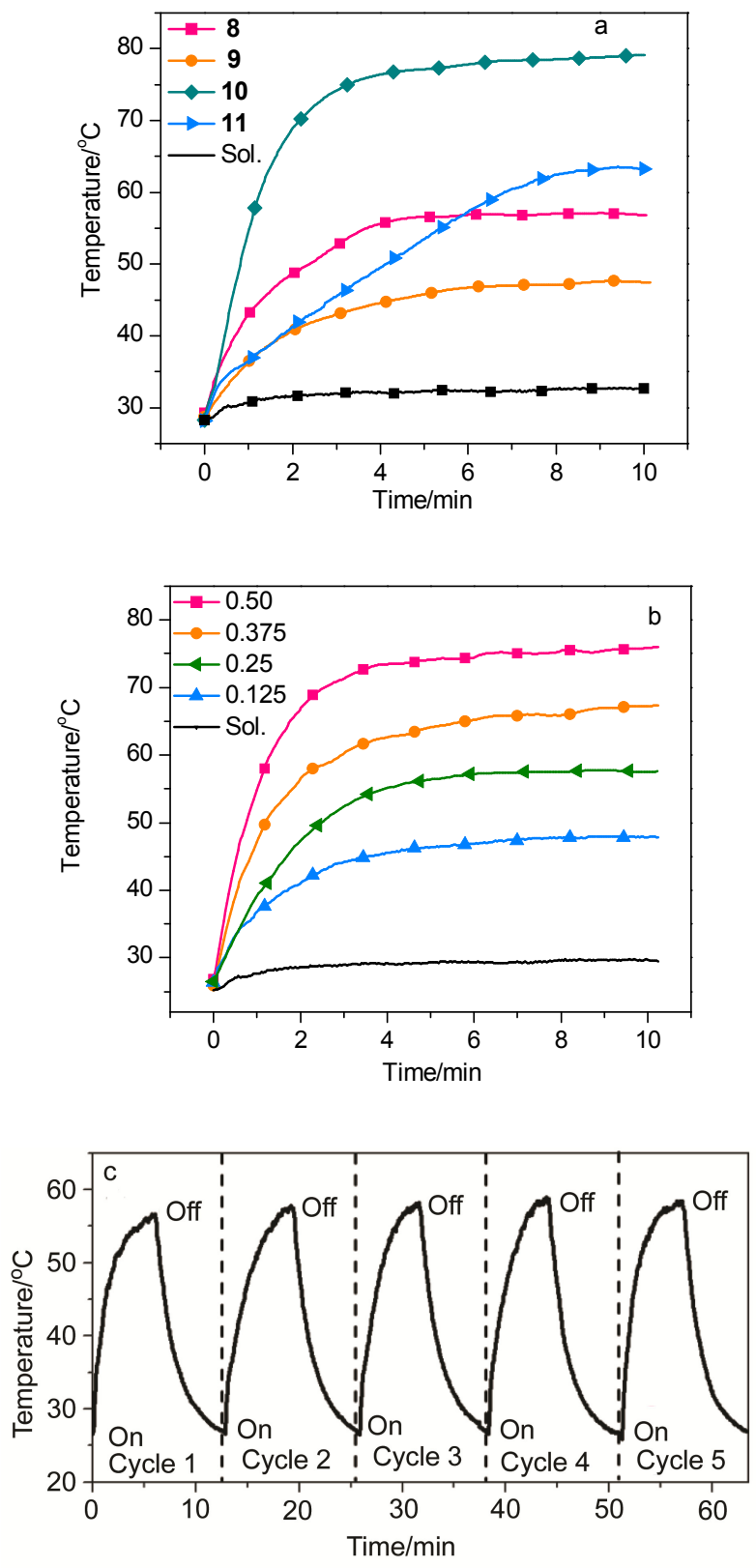

Figure 4 Temperature curves of (a) complexes $\mathbf{8} \sim \mathbf{1 1}(0.50$ $\mathrm{mg} / \mathrm{mL}$ ) irradiated by an $808 \mathrm{~nm}$ laser at a power density of 1.0 $\mathrm{W} / \mathrm{cm}^{2}$ in $\mathrm{H}_{2} \mathrm{O} / \mathrm{EtOH}$ solution (90 vot\%), (b) complex 10 at different concentrations irradiated by an $808 \mathrm{~nm}$ laser at a power density of $1.0 \mathrm{~W} / \mathrm{cm}^{2}$ in $\mathrm{H}_{2} \mathrm{O} / \mathrm{EtOH}$ solution $(90 \mathrm{vot} \%)$ and (c) a solution of complex $\mathbf{1 0}\left(0.25 \mathrm{mg} \cdot \mathrm{mL}^{-1}\right.$ in an $\mathrm{H}_{2} \mathrm{O} / \mathrm{EtOH}$ solution, $90 \mathrm{vot} \%$ ) irradiated by an $808 \mathrm{~nm}$ laser at a power density of 1.0 $\mathrm{W} \cdot \mathrm{cm}^{-2}$ with five laser on-off cycles

organic amino group and a good stability, which can be used as a photothermal material.

To explain the red-shifted absorptions and better photothermal performance of complexes $\mathbf{8} \sim \mathbf{1 1}$ (compared to $\mathbf{3}$ ), the molecular orbits of these complexes were analyzed by density functional theory (DFT). The results (Figure 5) show that the LUMO of complex 8 is composed of metallacycle [Os, $\mathrm{C}(1)-\mathrm{C}(9), 82.5 \%$ ] and 3-thiophenyl group 
$(11.3 \%)$ attached at $\mathrm{C}(9)$ of the metallacycle. While the HOMO of complex 8 is composed of metallacycle [Os(1), $\mathrm{C}(1)-\mathrm{C}(9), 73.3 \%]$ and 3-thiophenyl group (19.5\%). The $\mathrm{HOMO}-1$ is mainly located on Os center $(47.0 \%)$ and $\mathrm{C}(\mathrm{l})$ ligand (25.7\%). For HOMO - 2, it is mostly (91.6\%) located on the 4-(thiophen-3-yl)-phenyl group attached to C(3) of the metallacycle.
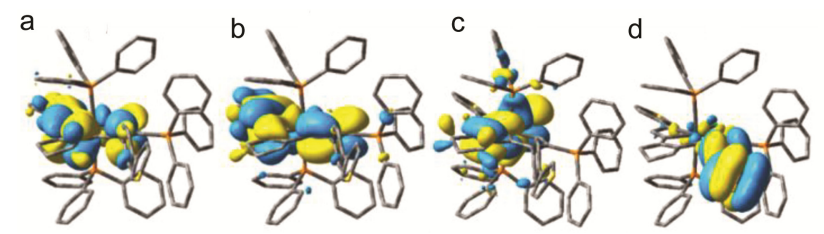

Figure 5 Orbital distributions of (a) LUMO, (b) HOMO, (c) HOMO -1 , and (d) HOMO -2 for complex 8

The time-dependent density functional theory (TD-DFT) calculations at B3LYP/6-31G(d) level showed that the maximum peak of complex $\mathbf{8}$ at $\lambda=714 \mathrm{~nm}$ is mostly $(93.6 \%)$ attributed to $\mathrm{HOMO} \rightarrow$ LUMO transitions, while maximum peak at $\lambda=561 \mathrm{~nm}$ can be fully attributed to HOMO $-1 \rightarrow$ LUMO transitions. As mentioned above, the HOMO and LUMO are dominated by the metallacycle and the substituent group attached to $\mathrm{C}(9)$ of the metallacycle. Thus, 3-thiophenyl group at C(9) of complex 8 plays an important role, influencing the absorption of complex $\mathbf{8}$, and further changes the photothermal behavior of cyclobutaosmapentalenes. On the contrary, the groups on $\mathrm{C}(3)$ have almost no influence on this behavior.

To verify this theoretical result, we further synthesized complexes 14 and 15 (Eq. 1), which have been characterized by NMR, HRMS and elemental analysis. Their absorption spectra and photothermal curves were measured and shown in Figure 6.

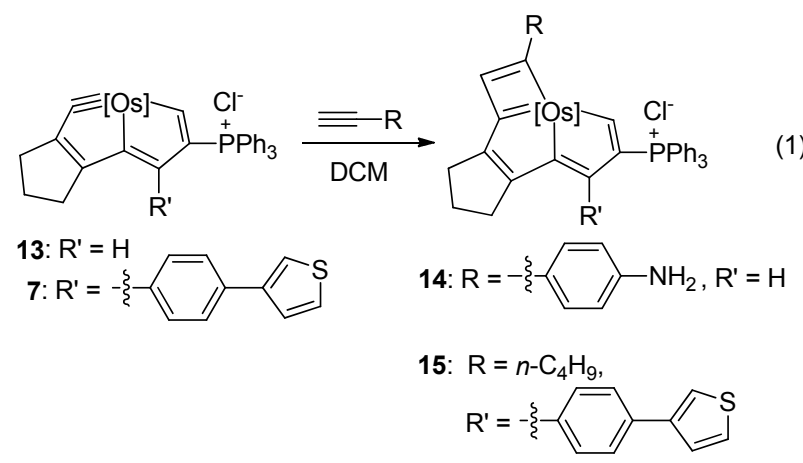

The results show that the maximum absorption peaks for complexes 10 and 14 are located at 723 and $742 \mathrm{~nm}$, respectively, while that for complex 15 is located at $664 \mathrm{~nm}$, close to 3. These results support that the hypothesis that the substituent group on $\mathrm{C}(9)$ of cyclobutaosmapentalenes dominates the maximum absorption values.

The solution containing complex 14 increases from $27{ }^{\circ} \mathrm{C}$ to $65{ }^{\circ} \mathrm{C}$ within $10 \mathrm{~min}$ when it is irradiated under $808 \mathrm{~nm}$ laser at $1 \mathrm{~W} / \mathrm{cm}^{2}$. Under similar radiation condi-
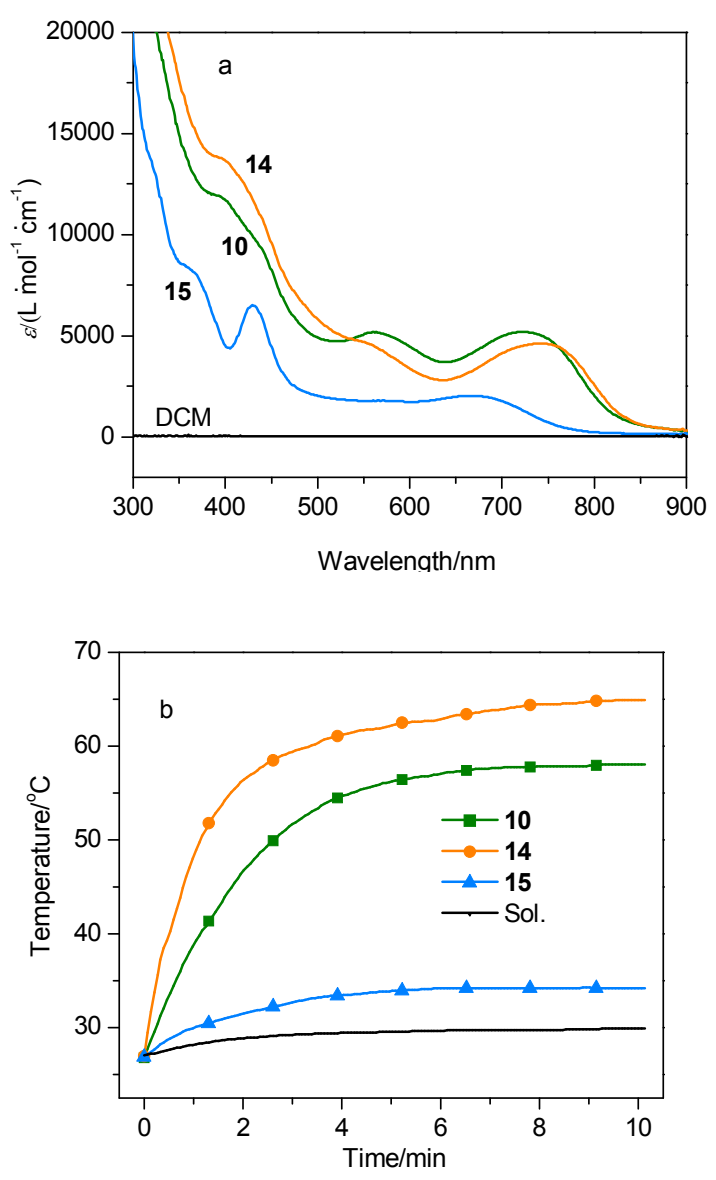

Figure 6 (a) UV-Vis-NIR absorption spectra of complexes 10, 14 and $15\left(5 \times 10^{-5} \mathrm{~mol} \cdot \mathrm{L}^{-1}\right)$ measured in dichloromethane at room temperature and (b) Temperature curves of complexes 10, 14 and $15(0.25 \mathrm{mg} / \mathrm{mL})$ irradiated by an $808 \mathrm{~nm}$ laser at power density of $1.0 \mathrm{~W} / \mathrm{cm}^{2}$ in water-ethanol solution (90 vot $\%$ )

tion, complex 15 only showed poorer photothermal ability, which is close to that of $\mathbf{3}$.

These experimental results are consistent with theoretical calculations. They both reveal that aryl groups on $\mathrm{C}(9)$ of the metallacycle play a vital role in the performance of cyclobutaosmapentalene in light absorption and photothermal behavior, while groups on $\mathrm{C}(3)$ barely influence the photophysical properties.

\section{Conclusions}

A series of photothermal cyclobutaosmapentalenes were successfully synthesized from the reaction of $\mathrm{OsCl}_{2}\left(\mathrm{PPh}_{3}\right)_{3}$ with an organic multiyne and $\mathrm{PPh}_{3}$, followed by a $[2+2]$ cycloaddition with terminal alkynes. The resulting cyclobutaosmapentalenes have larger conjugated frameworks and exhibit good photothermal behavior. Their UV-Vis-NIR absorption was measured and also analyzed by the density functional theory (DFT) calculations. The results show that the electron donating group results in the red-shift of the cyclobutaosmapentalenes and leads to good photothermal conversion. 


\section{Experimental section}

\subsection{General procedures}

NMR spectroscopic experiments were performed on a Bruker AVIII-500 spectrometer $\left({ }^{1} \mathrm{H}\right.$ NMR, 500.2 MHz; ${ }^{13} \mathrm{C}$ NMR, 125.8 MHz; $\left.{ }^{31} \mathrm{P} \mathrm{NMR}, 202.5 \mathrm{MHz}\right)$, or a Bruker AVIII-600 spectrometer $\left({ }^{1} \mathrm{H}\right.$ NMR, $600.1 \mathrm{MHz} ;{ }^{13} \mathrm{C}$ NMR, $150.9 \mathrm{MHz} ;{ }^{31} \mathrm{P} \mathrm{NMR}, 242.9 \mathrm{MHz}$ ) at room temperature. ${ }^{1} \mathrm{H}$ NMR and ${ }^{13} \mathrm{C}$ NMR chemical shifts $(\delta)$ are relative to tetramethylsilane. The high-resolution mass spectra (HRMS) were recorded on a Bruker En Apex Ultra 7.0T FT-MS. Elemental analysis were obtained on an Elementar Analysen system GmbH Vario EL III instrument. The theoretical molecular ion peak was calculated by Compass Isotope Pattern software supplied by Bruker Co. All syntheses were carried out under an inert atmosphere $\left(\mathrm{N}_{2}\right)$ by means of standard Schlenk techniques, unless otherwise stated. Tetrahydrofuran (THF) was distilled from sodium/benzophenone under $\mathrm{N}_{2}$ prior to use. Other solvents and reagents were used as received from commercial sources without further purification.

\subsection{Procedures for the synthesis of complexes $6 \sim$}

\section{2,14 and 15}

\subsubsection{Synthesis of complex 6}

A mixture of complex 4 (200 mg, $0.191 \mathrm{mmol}), 5$ (116 $\mathrm{mg}, 0.382 \mathrm{mmol})$ and triphenylphosphine $(250 \mathrm{mg}, 0.955$ $\mathrm{mmol})$ was stirred in dichloromethane (DCM) $(15 \mathrm{~mL})$ at $55{ }^{\circ} \mathrm{C}$ for $6 \mathrm{~h}$ to give a brown solution. The volume was then cooled down and reduced to about $2 \mathrm{~mL}$ under vacuum. Addition of $\mathrm{Et}_{2} \mathrm{O}(20 \mathrm{~mL})$ to the solution gave a brown precipitate, which was collected by filtration, washed with $\mathrm{Et}_{2} \mathrm{O}(10 \mathrm{~mL} \times 3)$, and dried under vacuum. The residue was purified by column chromatography (neutral alumina, eluent: $\mathrm{Me}_{2} \mathrm{CO}$ and $\left.\mathrm{MeOH} / \mathrm{DCM}, V: V=1: 25\right)$ to give $203 \mathrm{mg}$ (80\% yield) of $\mathbf{6}$ as a brown solid. ${ }^{1} \mathrm{H}$ NMR (600.1 $\left.\mathrm{MHz}, \mathrm{CD}_{2} \mathrm{Cl}_{2}\right) \delta: 13.17\left(\mathrm{br}, 1 \mathrm{H}, \mathrm{C}^{7} \mathrm{H}\right), 7.79 \sim 6.99(47 \mathrm{H}$ of $\mathrm{Ph}$ and $3 \mathrm{H}$ of thiophene groups), 6.05 (d, $J=8.2 \mathrm{~Hz}, 2 \mathrm{H}$, $\mathrm{Ph}), 2.50\left(\mathrm{~m}, 2 \mathrm{H}, \mathrm{C}^{10} \mathrm{H}\right), 1.71$ (tt, apparent quint, $J=7.4$, $\left.7.4 \mathrm{~Hz}, 2 \mathrm{H}, \mathrm{C}^{9} \mathrm{H}\right), 1.12\left(\mathrm{t}, J=7.4 \mathrm{~Hz}, 2 \mathrm{H}, \mathrm{C}^{8} \mathrm{H}\right) ;{ }^{31} \mathrm{P}\left\{{ }^{1} \mathrm{H}\right\}$ NMR (242.9 MHz, $\left.\mathrm{CD}_{2} \mathrm{Cl}_{2}\right) \delta: 5.68\left(\mathrm{t},{ }^{4} J(\mathrm{P}, \mathrm{P})=5.7 \mathrm{~Hz}\right.$, $\mathrm{CPPh}_{3}$ ), 3.76 (br, $\left.\mathrm{OsPPh}_{3}\right) ;{ }^{13} \mathrm{C}\left\{{ }^{1} \mathrm{H}\right\}$ NMR (150.9 MHz, $\mathrm{CD}_{2} \mathrm{Cl}_{2}$, plus ${ }^{1} \mathrm{H}^{13}{ }^{13} \mathrm{C} \mathrm{HMBC}$ and HSQC and ${ }^{13} \mathrm{C}$-dept 135$)$ $\delta$ : $318.2\left(\mathrm{br}, \mathrm{C}^{1}\right), 214.9\left(\mathrm{br}, \mathrm{C}^{7}\right), 181.0\left(\mathrm{~s}, \mathrm{C}^{5}\right), 176.6(\mathrm{br}$, $\left.\mathrm{C}^{6}\right), 168.8\left[\mathrm{~d},{ }^{3} J(\mathrm{CP})=22.2 \mathrm{~Hz}, \mathrm{C}^{4}\right], 163.9\left[\mathrm{~d},{ }^{2} J(\mathrm{CP})=\right.$ $16.6 \mathrm{~Hz}, \mathrm{C}^{3}$ ], $134.7\left(\mathrm{br}, \mathrm{C}^{2}\right), 141.2 \sim 125.5(\mathrm{Ph}$, thiophene, and $\mathrm{C}^{2}$ mentioned above), $121.2(\mathrm{~s}$, thiophene), $120.9(\mathrm{~d}$, $\left.{ }^{1} J(\mathrm{CP})=90.7 \mathrm{~Hz}, \mathrm{Ph}\right), 35.8\left(\mathrm{~s}, \mathrm{C}^{8}\right), 29.8\left(\mathrm{~s}, \mathrm{C}^{10}\right), 29.8(\mathrm{~s}$, $\mathrm{C}^{9}$ ); HRMS (ESI) calcd for $\mathrm{C}_{74} \mathrm{H}_{59} \mathrm{ClOsP}_{3} \mathrm{~S}\left[\mathrm{M}-\mathrm{Cl}^{-}\right.$] 1299.2848, found 1299.2886. Anal calcd for $\mathrm{C}_{74} \mathrm{H}_{59} \mathrm{Cl}_{2-}$ $\mathrm{OsP}_{3} \mathrm{~S}$ : C 66.61, H 4.46; found C 66.56, H 4.23.

\subsubsection{Synthesis of complex 7}

Complex 6 (200 mg, $0.150 \mathrm{mmol})$ was dissolved in $\mathrm{DCM}(15 \mathrm{~mL})$, then $\mathrm{HCl} / \mathrm{Et}_{2} \mathrm{O}$ solution $(50 \mathrm{wt} \%, 11.0 \mathrm{mg}$, $0.150 \mathrm{mmol}$ ) was added to the solution and the mixture was stirred for $5 \mathrm{~min}$. Afterwards, the mixture was reduced to dryness and washed by $\mathrm{Et}_{2} \mathrm{O}$ to get $190 \mathrm{mg}$ (95\% yield) of complex 7 as a brown solid. ${ }^{1} \mathrm{H}$ NMR $(600.1 \mathrm{MHz}$, $\left.\mathrm{CD}_{2} \mathrm{Cl}_{2}\right) \delta: 13.48\left(\mathrm{dt},{ }^{3} J(\mathrm{HP})=18.6 \mathrm{~Hz},{ }^{3} J(\mathrm{HP})=2.5 \mathrm{~Hz}\right.$, $\left.1 \mathrm{H}, \mathrm{C}^{1} \mathrm{H}\right), 7.06\left(\mathrm{~d}, J=7.6 \mathrm{~Hz}, 2 \mathrm{H}, \mathrm{C}^{12} \mathrm{H}\right), 7.76 \sim 6.83(45 \mathrm{H}$ of $\mathrm{PPh}, 3 \mathrm{H}$ of thiophene groups and $2 \mathrm{H}$ of $\mathrm{C}^{12} \mathrm{H}$ mentioned above), 6.39 (d, J=7.6 Hz, 2H, $\left.\mathrm{C}^{11} \mathrm{H}\right), 2.02\left(\mathrm{br}, 2 \mathrm{H}, \mathrm{C}^{10} \mathrm{H}\right)$, 1.21 (tt, apparent quint, $\left.J=7.3,7.3 \mathrm{~Hz}, 2 \mathrm{H}, \mathrm{C}^{9} \mathrm{H}\right), 0.48(\mathrm{t}$, $\left.J=7.3 \mathrm{~Hz}, 2 \mathrm{H}, \mathrm{C}^{8} \mathrm{H}\right) ;{ }^{31} \mathrm{P}\left\{{ }^{1} \mathrm{H}\right\} \mathrm{NMR}\left(242.9 \mathrm{MHz}, \mathrm{CD}_{2} \mathrm{Cl}_{2}\right)$ $\delta: 13.63\left(\mathrm{br}, \mathrm{CPPh}_{3}\right), 9.13\left(\mathrm{~d}, J=5.0 \mathrm{~Hz}, \mathrm{OsPPh}_{3}\right) ;{ }^{13} \mathrm{C}\left\{{ }^{1} \mathrm{H}\right\}$ NMR (150.9 MHz, $\mathrm{CD}_{2} \mathrm{Cl}_{2}$, plus ${ }^{1} \mathrm{H}^{13} \mathrm{C} \mathrm{HMBC}$ and HSQC and ${ }^{13} \mathrm{C}$-dept 135) $\delta$ : $320.3\left[\mathrm{td},{ }^{2} J(\mathrm{CP})=16.3 \mathrm{~Hz}\right.$, $\left.{ }^{4} J(\mathrm{CP})=5.7 \mathrm{~Hz}, \mathrm{C}^{7}\right], 220.2\left[\mathrm{~d},{ }^{2} J(\mathrm{CP})=26.9 \mathrm{~Hz}, \mathrm{C}^{1}\right]$, $192.5\left(\mathrm{~s}, \mathrm{C}^{5}\right), 170.0\left[\mathrm{~d},{ }^{3} J(\mathrm{CP})=18.4 \mathrm{~Hz}, \mathrm{C}^{4}\right], 166.6(\mathrm{~s}$, $\left.\mathrm{C}^{6}\right), 153.0\left[\mathrm{~d},{ }^{2} J(\mathrm{CP})=22.8 \mathrm{~Hz}, \mathrm{C}^{3}\right], 132.4\left[\mathrm{dt},{ }^{1} J(\mathrm{CP})=\right.$ $\left.71.0 \mathrm{~Hz},{ }^{3} J(\mathrm{CP})=5.4 \mathrm{~Hz}, \mathrm{C}^{2}\right], 140.9 \sim 125.3(\mathrm{Ph}$, thiophene and $\mathrm{C}^{2}$ mentioned above), 120.9 (s, thiophene), $120.5\left[\mathrm{~d},{ }^{1} J(\mathrm{CP})=87.8 \mathrm{~Hz}, \mathrm{Ph}\right], 34.0\left(\mathrm{~s}, \mathrm{C}^{8}\right), 29.3\left(\mathrm{~s}, \mathrm{C}^{9}\right)$, 24.7(s, C ${ }^{10}$ ); HRMS (ESI) calcd for $\mathrm{C}_{74} \mathrm{H}_{59} \mathrm{ClOsP}_{3} \mathrm{~S}$ [M$\mathrm{Cl}^{-}$] 1299.2848, found 1299.2910. Anal. calcd for $\mathrm{C}_{74} \mathrm{H}_{59} \mathrm{Cl}_{2} \mathrm{OsP}_{3} \mathrm{~S}$ : C 66.61, H 4.46; found C 67.00, H 4.47.

\subsubsection{Synthesis of complex 8}

A mixture of complex $7(200 \mathrm{mg}, 0.150 \mathrm{mmol})$ and 3-ethynylthiophene $(48.6 \mathrm{mg}, 0.450 \mathrm{mmol})$ was stirred in $\mathrm{CH}_{2} \mathrm{Cl}_{2}(15 \mathrm{~mL})$ at room temperature for $2 \mathrm{~h}$ to give a green solution. The volume was reduced to about $2 \mathrm{~mL}$ under vacuum. Addition of $\mathrm{Et}_{2} \mathrm{O}(20 \mathrm{~mL})$ to the solution gave a grey precipitate, which was collected by filtration, washed with $\mathrm{Et}_{2} \mathrm{O}(10 \mathrm{~mL} \times 3)$, and dried under vacuum. The residue was purified by column chromatography (silica gel, eluent: $\mathrm{Me}_{2} \mathrm{CO}$ and $\mathrm{MeOH} / \mathrm{DCM}, V: V=1: 30$ ) to give173 $\mathrm{mg}\left(80 \%\right.$ yield) of $\mathbf{8}$ as a green solid. ${ }^{1} \mathrm{H}$ NMR $\left(600.1 \mathrm{MHz}, \mathrm{CD}_{2} \mathrm{Cl}_{2}\right) \delta: 13.62\left[\mathrm{~d},{ }^{3} J(\mathrm{HP})=18.9 \mathrm{~Hz}, 1 \mathrm{H}\right.$, $\left.\mathrm{C}^{1} \mathrm{H}\right], 7.28$ (s, $1 \mathrm{H}, \mathrm{C}^{8} \mathrm{H}$, determined by ${ }^{1} \mathrm{H}-{ }^{13} \mathrm{C}$ HSQC), $7.93 \sim 6.64(47 \mathrm{H}$ of $\mathrm{Ph}, 6 \mathrm{H}$ of thiophene groups and $1 \mathrm{H}$ of $\mathrm{C}^{8} \mathrm{H}$ mentioned above), $6.27\left(\mathrm{~d}, J=7.9 \mathrm{~Hz}, 2 \mathrm{H}, \mathrm{C}^{13} \mathrm{H}\right)$, $1.76\left(\mathrm{t}, J=7.4 \mathrm{~Hz}, 2 \mathrm{H}, \mathrm{C}^{12} \mathrm{H}\right), 1.36(\mathrm{tt}$, apparent quint, $J=$ 7.4, 7.4 Hz, 2H, $\left.\mathrm{C}^{11} \mathrm{H}\right), 0.13\left(\mathrm{t}, J=7.4 \mathrm{~Hz}, 2 \mathrm{H}, \mathrm{C}^{10} \mathrm{H}\right)$; ${ }^{31} \mathrm{P}\left\{{ }^{1} \mathrm{H}\right\} \mathrm{NMR}\left(242.9 \mathrm{MHz}, \mathrm{CD}_{2} \mathrm{Cl}_{2}\right) \delta: 10.21\left(\mathrm{br}, \mathrm{CPPh}_{3}\right)$, - $16.13\left(\mathrm{br}, \mathrm{OsPPh}_{3}\right) ;{ }^{13} \mathrm{C}\left\{{ }^{1} \mathrm{H}\right\} \mathrm{NMR}\left(150.9 \mathrm{MHz}, \mathrm{CD}_{2} \mathrm{Cl}_{2}\right.$, plus ${ }^{1} \mathrm{H}_{-}{ }^{13} \mathrm{C}$ HMBC and HSQC and ${ }^{13} \mathrm{C}$-dept 135) $\delta$ : 234.6 (br, $\left.\mathrm{C}^{1}\right), 188.9\left(\mathrm{~s}, \mathrm{C}^{5}\right), 181.2\left[\mathrm{t},{ }^{2} J(\mathrm{CP})=6.7 \mathrm{~Hz}, \mathrm{C}^{7}\right], 177.1$ $\left[\mathrm{dt},{ }^{3} J(\mathrm{CP})=23.6 \mathrm{~Hz},{ }^{2} J(\mathrm{CP})=5.9 \mathrm{~Hz}, \mathrm{C}^{4}\right], 165.4\left(\mathrm{~s}, \mathrm{C}^{6}\right)$, $164.8\left[\mathrm{~d},{ }^{2} J(\mathrm{CP})=24.1 \mathrm{~Hz}, \mathrm{C}^{3}\right], 157.6\left(\mathrm{br}, \mathrm{C}^{9}\right), 148.9[\mathrm{t}$, $\left.{ }^{3} J(\mathrm{CP})=5.0 \mathrm{~Hz}, \mathrm{C}^{8}\right], 134.4\left(\mathrm{br}, \mathrm{C}^{2}\right), 146.6 \sim 125.1(\mathrm{Ph}$, thiophene and $\mathrm{C}^{2}$ mentioned above), 122.0 (s, thiophene), 120.7 (s, thiophene), 120.6 [d, $\left.{ }^{1} J(\mathrm{CP})=88.1 \mathrm{~Hz}, \mathrm{Ph}\right], 34.2$ $\left(\mathrm{s}, \mathrm{C}^{10}\right), 28.8\left(\mathrm{~s}, \mathrm{C}^{11}\right), 22.9\left(\mathrm{~s}, \mathrm{C}^{12}\right)$; HRMS (ESI) calcd for $\mathrm{C}_{80} \mathrm{H}_{63} \mathrm{ClOsP}_{3} \mathrm{~S}_{2}\left[\mathrm{M}-\mathrm{Cl}^{-}\right]$1407.2882, found 1407.2821. Anal. calcd for $\mathrm{C}_{80} \mathrm{H}_{63} \mathrm{Cl}_{2} \mathrm{OsP}_{3} \mathrm{~S}_{2}$ : C 66.61, $\mathrm{H} 4.40$; found $\mathrm{C}$ 66.30, H 4.02 .

\subsubsection{Synthesis of complex 9}

A mixture of complex 7 (200 mg, $0.150 \mathrm{mmol})$ and 4-ethynylpyridin-1-ium chloride $(62.6 \mathrm{mg}, 0.450 \mathrm{mmol})$ was stirred in DCM $(10 \mathrm{~mL})$ at room temperature for $2 \mathrm{~h}$ to give a green solution. The volume was reduced to about 2 $\mathrm{mL}$ under vacuum. Addition of $\mathrm{Et}_{2} \mathrm{O}(20 \mathrm{~mL})$ to the solu- 
tion gave a grey precipitate, which was collected by filtration, washed with $\mathrm{Et}_{2} \mathrm{O}(10 \mathrm{~mL} \times 3)$, and dried under vacuum. The residue was purified by column chromatography (silica gel, eluent: $\mathrm{Me}_{2} \mathrm{CO}$ and $\mathrm{MeOH} / \mathrm{DCM}, V: V=1:$ $30)$ to give $155 \mathrm{mg}$ ( $72 \%$ yield) of 9 as a green solid. ${ }^{1} \mathrm{H}$ NMR $\left(600.1 \mathrm{MHz}, \mathrm{CD}_{2} \mathrm{Cl}_{2}\right) \delta: 13.97\left[\mathrm{~d},{ }^{3} J(\mathrm{HP})=18.2 \mathrm{~Hz}\right.$, $\left.1 \mathrm{H}, \mathrm{C}^{1} \mathrm{H}\right], 7.38\left(\mathrm{~s}, 1 \mathrm{H}, \mathrm{C}^{8} \mathrm{H}\right.$, determined by ${ }^{1} \mathrm{H}-{ }^{13} \mathrm{C}$ HSQC), $7.94 \sim 6.88$ (47H of $\mathrm{Ph}, 3 \mathrm{H}$ of thiophene groups, $4 \mathrm{H}$ of pyridine groups and $1 \mathrm{H}$ of $\mathrm{C}^{8} \mathrm{H}$ mentioned above), 6.34 (br, 2H, $\mathrm{C}^{13} \mathrm{H}$ ), 1.77 (t, J=7.2 Hz, 2H, $\mathrm{C}^{12} \mathrm{H}$ ), 1.32 (tt, apparent quint, $\left.J=7.2,7.2 \mathrm{~Hz}, 2 \mathrm{H}, \mathrm{C}^{11} \mathrm{H}\right), 0.05(\mathrm{t}, J=7.2 \mathrm{~Hz}$, $\left.2 \mathrm{H}, \mathrm{C}^{10} \mathrm{H}\right) ;{ }^{31} \mathrm{P}\left\{{ }^{1} \mathrm{H}\right\}$ NMR $\left(242.9 \mathrm{MHz}, \mathrm{CD}_{2} \mathrm{Cl}_{2}\right) \delta: 10.50$ $\left(\mathrm{br}, \mathrm{CPPh}_{3}\right),-17.80\left(\mathrm{br}, \mathrm{OsPPh}_{3}\right) ;{ }^{13} \mathrm{C}\left\{{ }^{1} \mathrm{H}\right\} \mathrm{NMR}(150.9$ $\mathrm{MHz}, \mathrm{CD}_{2} \mathrm{Cl}_{2}$, plus ${ }^{1} \mathrm{H}^{-13} \mathrm{C} \mathrm{HMBC}$ and HSQC and ${ }^{13} \mathrm{C}$-dept 135) $\delta$ : $235.3\left(\mathrm{br}, \mathrm{C}^{1}\right), 190.4\left(\mathrm{~s}, \mathrm{C}^{5}\right), 182.1\left[\mathrm{t},{ }^{2} J(\mathrm{CP})=7.0\right.$ $\left.\mathrm{Hz}, \mathrm{C}^{7}\right], 179.4\left[\mathrm{dt},{ }^{3} J(\mathrm{CP})=23.3 \mathrm{~Hz},{ }^{2} J(\mathrm{CP})=5.4 \mathrm{~Hz}, \mathrm{C}^{4}\right]$, $167.6\left[\mathrm{~d},{ }^{2} J(\mathrm{CP})=23.6 \mathrm{~Hz}, \mathrm{C}^{3}\right], 167.2\left(\mathrm{~s}, \mathrm{C}^{6}\right), 154.8[\mathrm{t}$, $\left.{ }^{2} J(\mathrm{CP})=10.8 \mathrm{~Hz}, \mathrm{C}^{9}\right], 153.0\left[\mathrm{t},{ }^{3} J(\mathrm{CP})=4.7 \mathrm{~Hz}, \mathrm{C}^{8}\right], 136.0$ (br, $\left.\mathrm{C}^{2}\right), 151.7 \sim 125.6\left(\mathrm{Ph}\right.$, thiophene, pyridine and $\mathrm{C}^{2}$ mentioned above), 121.0 (s, thiophene), $120.4\left[\mathrm{~d},{ }^{1} J(\mathrm{CP})=\right.$ $89.2 \mathrm{~Hz}, \mathrm{Ph}$ ], 119.6 (s, pyridine), $35.0\left(\mathrm{~s}, \mathrm{C}^{10}\right), 29.0(\mathrm{~s}$, $\left.\mathrm{C}^{11}\right), 23.0\left(\mathrm{~s}, \mathrm{C}^{12}\right)$; HRMS (ESI) calcd for $\mathrm{C}_{81} \mathrm{H}_{64} \mathrm{CINOsP}_{3} \mathrm{~S}$ $\left[\mathrm{M}-\mathrm{Cl}^{-}\right]$1402.3276, found 1402.3283. Anal. calcd for $\mathrm{C}_{81} \mathrm{H}_{64} \mathrm{Cl}_{2} \mathrm{NOsP}_{3} \mathrm{~S}$ : C $67.68, \mathrm{H} 4.49, \mathrm{~N} 0.97$; found $\mathrm{C}$ 67.50, H 4.81, N 0.73 .

\subsubsection{Synthesis of complex $\mathbf{1 0}$}

A mixture of complex $7(200 \mathrm{mg}, 0.150 \mathrm{mmol})$ and 4-ethynylaniline $(52.7 \mathrm{mg}, 0.450 \mathrm{mmol})$ was stirred in DCM $(10 \mathrm{~mL})$ at room temperature for $2 \mathrm{~h}$ to give a green solution. The volume was reduced to about $2 \mathrm{~mL}$ under vacuum. Addition of $\mathrm{Et}_{2} \mathrm{O}(20 \mathrm{~mL})$ to the solution gave a grey precipitate, which was collected by filtration, washed with $\mathrm{Et}_{2} \mathrm{O}(10 \mathrm{~mL} \times 3)$, and dried under vacuum. The residue was purified by column chromatography (silica gel, eluent: $\mathrm{Me}_{2} \mathrm{CO}$ and $\left.\mathrm{MeOH} / \mathrm{DCM}, V: V=1: 30\right)$ to give $113 \mathrm{mg}$ (52\% yield) of $\mathbf{1 0}$ as a green solid. ${ }^{1} \mathrm{H}$ NMR (600.1 $\left.\mathrm{MHz}, \mathrm{CD}_{2} \mathrm{Cl}_{2}\right) \delta: 13.47\left[\mathrm{~d},{ }^{3} J(\mathrm{HP})=19.3 \mathrm{~Hz}, 1 \mathrm{H}, \mathrm{C}^{1} \mathrm{H}\right.$ ], 7.27 (s, $1 \mathrm{H}, \mathrm{C}^{8} \mathrm{H}$, determined by ${ }^{1} \mathrm{H}-{ }^{13} \mathrm{C}$ HSQC), $7.72 \sim$ $6.87\left(47 \mathrm{H}\right.$ of $\mathrm{Ph}, 3 \mathrm{H}$ of thiophene groups and $1 \mathrm{H}$ of $\mathrm{C}^{8} \mathrm{H}$ mentioned above), 6.59 (d, $J=8.5 \mathrm{~Hz}, 2 \mathrm{H}, \mathrm{Ph}$ ), 6.30 (br, $2 \mathrm{H}, \mathrm{C}^{13} \mathrm{H}$ ), 6.15 (br, 2H, Ph), 1.67 (t, $J=7.1 \mathrm{~Hz}, 2 \mathrm{H}$, $\left.\mathrm{C}^{12} \mathrm{H}\right), 1.31$ (tt, apparent quint, $J=7.1,7.1 \mathrm{~Hz}, 2 \mathrm{H}, \mathrm{C}^{11} \mathrm{H}$ ), $0.20\left(\mathrm{t}, J=7.1 \mathrm{~Hz}, 2 \mathrm{H}, \mathrm{C}^{10} \mathrm{H}\right) ;{ }^{31} \mathrm{P}\left\{{ }^{1} \mathrm{H}\right\} \mathrm{NMR}(242.9 \mathrm{MHz}$, $\left.\mathrm{CD}_{2} \mathrm{Cl}_{2}\right) \delta: 10.03$ (br, $\mathrm{CPPh}_{3}$ ), - 16.83 (br, $\mathrm{OsPPh}_{3}$ ); ${ }^{13} \mathrm{C}\left\{{ }^{1} \mathrm{H}\right\}$ NMR $\left(150.9 \mathrm{MHz}, \mathrm{CD}_{2} \mathrm{Cl}_{2}\right.$, plus ${ }^{1} \mathrm{H}^{13}{ }^{13} \mathrm{CMBC}$ and HSQC and ${ }^{13} \mathrm{C}$-dept 135) $\delta: 234.3\left(\mathrm{br}, \mathrm{C}^{1}\right), 187.5(\mathrm{~s}$, $\left.\mathrm{C}^{5}\right), 179.7\left[\mathrm{t},{ }^{2} J(\mathrm{CP})=6.7 \mathrm{~Hz}, \mathrm{C}^{7}\right], 175.5\left(\mathrm{br}, \mathrm{C}^{4}\right), 169.1[\mathrm{t}$, $\left.{ }^{2} J(\mathrm{CP})=10.3 \mathrm{~Hz}, \mathrm{C}^{9}\right], 164.3\left(\mathrm{~s}, \mathrm{C}^{6}\right), 163.0\left[\mathrm{~d},{ }^{2} J(\mathrm{CP})=\right.$ $24.7 \mathrm{~Hz}, \mathrm{C}^{3}$ ], 148.6 (s, C-NH $\mathrm{NH}_{2}, 146.5$ (s, C $\left.{ }^{8}\right), 134.5$ (br, $\left.\mathrm{C}^{2}\right), \quad 148.6 \sim 125.3\left(\mathrm{Ph}\right.$, thiophene and $\mathrm{C}^{2}$ mentioned above), $121.0\left[\mathrm{~d},{ }^{1} J(\mathrm{CP})=88.2 \mathrm{~Hz}, \mathrm{Ph}\right], 120.7$ (s, thiophene), $112.9(\mathrm{~s}, \mathrm{Ph}), 33.9\left(\mathrm{~s}, \mathrm{C}^{10}\right), 28.9\left(\mathrm{~s}, \mathrm{C}^{11}\right), 23.0(\mathrm{~s}$, $\mathrm{C}^{12}$ ); HRMS (ESI) calcd for $\mathrm{C}_{82} \mathrm{H}_{66} \mathrm{ClNOsP}_{3} \mathrm{~S}\left[\mathrm{M}-\mathrm{Cl}^{-}\right]$ 1416.3427, found 1416.3353. Anal. calcd for $\mathrm{C}_{82} \mathrm{H}_{66} \mathrm{Cl}_{2-}$ $\mathrm{NOsP}_{3} \mathrm{~S}$ : C 67.85, H 4.58, N 0.96; found C 68.02, H 4.78, $\mathrm{N} 0.82$.

\subsubsection{Synthesis of complex 11}

A mixture of complex $7(200 \mathrm{mg}, 0.150 \mathrm{mmol})$ and 4-ethynylbenzonitrile $(57.2 \mathrm{mg}, 0.450 \mathrm{mmol})$ was stirred in DCM $(10 \mathrm{~mL})$ at room temperature for $2 \mathrm{~h}$ to give a green solution. The volume was reduced to about $2 \mathrm{~mL}$ under vacuum. Addition of $\mathrm{Et}_{2} \mathrm{O}(20 \mathrm{~mL})$ to the solution gave a grey precipitate, which was collected by filtration, washed with $\mathrm{Et}_{2} \mathrm{O}(10 \mathrm{~mL} \times 3)$, and dried under vacuum. The residue was purified by column chromatography (silica gel, eluent: $\mathrm{Me}_{2} \mathrm{CO}$ and $\left.\mathrm{MeOH} / \mathrm{DCM}, V: V=1: 30\right)$ to give $147 \mathrm{mg}$ (67\% yield) of 11 as a green solid. ${ }^{1} \mathrm{H}$ NMR (600.1 $\left.\mathrm{MHz}, \mathrm{CD}_{2} \mathrm{Cl}_{2}\right) \delta: 13.95\left[\mathrm{~d},{ }^{3} J(\mathrm{HP})=18.2 \mathrm{~Hz}, 1 \mathrm{H}, \mathrm{C}^{1} \mathrm{H}\right]$, 7.36 (s, $1 \mathrm{H}, \mathrm{C}^{8} \mathrm{H}$, determined by ${ }^{1} \mathrm{H}_{-}{ }^{13} \mathrm{C}$ HSQC), $7.73 \sim$ $6.88\left(49 \mathrm{H}\right.$ of $\mathrm{Ph}, 3 \mathrm{H}$ of thiophene groups and $1 \mathrm{H}$ of $\mathrm{C}^{8} \mathrm{H}$ mentioned above), 6.60 (br, 2H, Ph), 6.35 (br, 2H, Ph), $1.77\left(\mathrm{t}, J=7.6 \mathrm{~Hz}, 2 \mathrm{H}, \mathrm{C}^{12} \mathrm{H}\right), 1.31(\mathrm{tt}$, apparent quint, $J=$ 7.6, 7.6 Hz, 2H, $\left.\mathrm{C}^{11} \mathrm{H}\right),-0.01\left(\mathrm{t}, J=7.6 \mathrm{~Hz}, 2 \mathrm{H}, \mathrm{C}^{10} \mathrm{H}\right)$; ${ }^{31} \mathrm{P}\left\{{ }^{1} \mathrm{H}\right\} \mathrm{NMR}\left(242.9 \mathrm{MHz}, \mathrm{CD}_{2} \mathrm{Cl}_{2}\right) \delta: 10.49\left(\mathrm{br}, \mathrm{CPPh}_{3}\right)$, -17.95 (br, OsPPh $) ;{ }^{13} \mathrm{C}\left\{{ }^{1} \mathrm{H}\right\}$ NMR (150.9 MHz, $\mathrm{CD}_{2} \mathrm{Cl}_{2}$, plus ${ }^{1} \mathrm{H}^{13}{ }^{13} \mathrm{HMBC}$ and HSQC and ${ }^{13} \mathrm{C}$-dept 135) $\delta: 235.0$ (br, $\left.\mathrm{C}^{1}\right), 190.4\left(\mathrm{~s}, \mathrm{C}^{5}\right), 182.0\left[\mathrm{t},{ }^{2} J(\mathrm{CP})=7.4 \mathrm{~Hz}, \mathrm{C}^{7}\right], 179.3$ $\left[\mathrm{dt},{ }^{3} J(\mathrm{CP})=23.1 \mathrm{~Hz},{ }^{2} J(\mathrm{CP})=5.9 \mathrm{~Hz}, \mathrm{C}^{4}\right], 167.4[\mathrm{~d}$, $\left.{ }^{2} J(\mathrm{CP})=23.5 \mathrm{~Hz}, \mathrm{C}^{3}\right], 167.1\left(\mathrm{~s}, \mathrm{C}^{6}\right), 156.1\left[\mathrm{t},{ }^{2} J(\mathrm{CP})=9.3\right.$ $\left.\mathrm{Hz}, \mathrm{C}^{9}\right], 152.8\left[\mathrm{t},{ }^{3} J(\mathrm{CP})=4.7 \mathrm{~Hz}, \mathrm{C}^{8}\right], 134.6\left(\mathrm{br}, \mathrm{C}^{2}\right)$, $151.7 \sim 125.6\left(\mathrm{Ph}\right.$, thiophene and $\mathrm{C}^{2}$ mentioned above), 121.1 (s, thiophene), 120.5 [d, $\left.{ }^{1} J(\mathrm{CP})=88.4 \mathrm{~Hz}, \mathrm{Ph}\right], 119.8$ $(\mathrm{s}, \mathrm{Ph}), 109.0(\mathrm{~s}, \mathrm{CN}), 35.0\left(\mathrm{~s}, \mathrm{C}^{10}\right), 29.1\left(\mathrm{~s}, \mathrm{C}^{11}\right), 23.0(\mathrm{~s}$, $\mathrm{C}^{12}$ ); HRMS (ESI) calcd for $\mathrm{C}_{83} \mathrm{H}_{64} \mathrm{ClNOsP}_{3} \mathrm{~S}\left[\mathrm{M}-\mathrm{Cl}^{-}\right]$ 1426.3276, found 1426.3274. Anal. calcd for $\mathrm{C}_{83} \mathrm{H}_{64} \mathrm{Cl}_{2} \mathrm{~N}-$ $\mathrm{OsP}_{3} \mathrm{~S}$ : C 68.21, H 4.41, N 0.96; found C 68.34, H 4.69, N 0.72 .

\subsubsection{Synthesis of complex 12}

Method 1: A mixture of complex 8 (100 mg, 0.069 $\mathrm{mmol})$ and sodium tetrafluoroborate $(100 \mathrm{mg}, 0.909 \mathrm{mmol})$ was stirred in DCM $(10 \mathrm{~mL})$ at room temperature for $12 \mathrm{~h}$ to exchange the anion. The volume was filtrated and reduced to about $2 \mathrm{~mL}$ under vacuum. Addition of $\mathrm{Et}_{2} \mathrm{O}(20$ $\mathrm{mL})$ to the solution gave a grey precipitate, which was collected by filtration, washed with $\mathrm{Et}_{2} \mathrm{O}(10 \mathrm{~mL} \times 3)$, and dried under vacuum to give $95 \mathrm{mg}$ ( $92 \%$ yield) of $\mathbf{1 2}$ as a green solid.

Method 2: A mixture of complex 6 (200 mg, 0.150 $\mathrm{mmol})$, 3-ethynylthiophene (48.6 $\mathrm{mg}, 0.450 \mathrm{mmol})$ and tetrafluoroboric acid solution $(900 \mu \mathrm{L}, 0.50 \mathrm{~mol} / \mathrm{L})$ was stirred in DCM $(15 \mathrm{~mL})$ at room temperature for $2 \mathrm{~h}$ to give a green solution. The volume was reduced to about 2 $\mathrm{mL}$ under vacuum. Addition of $\mathrm{Et}_{2} \mathrm{O}(20 \mathrm{~mL})$ to the solution gave a grey precipitate, which was collected by filtration, washed with $\mathrm{Et}_{2} \mathrm{O}(10 \mathrm{~mL} \times 3)$, and dried under vacuum. The residue was purified by column chromatography (silica gel, eluent: $\mathrm{Me}_{2} \mathrm{CO}$ and $\mathrm{MeOH} / \mathrm{DCM}, V: V=1$ : $30)$ to give $141 \mathrm{mg}$ ( $65 \%$ yield) of $\mathbf{1 2}$ as a green solid. ${ }^{1} \mathrm{H}$ NMR (500.1 MHz, $\left.\mathrm{CD}_{2} \mathrm{Cl}_{2}\right) \delta: 13.55\left[\mathrm{~d},{ }^{3} J(\mathrm{HP})=18.8 \mathrm{~Hz}\right.$, $\left.1 \mathrm{H}, \mathrm{C}^{1} \mathrm{H}\right], 7.21$ (s, $1 \mathrm{H}, \mathrm{C}^{8} \mathrm{H}$, determined by ${ }^{1} \mathrm{H}-{ }^{13} \mathrm{C}$ HSQC), $7.96 \sim 6.57(47 \mathrm{H}$ of $\mathrm{Ph}, 6 \mathrm{H}$ of thiophene groups and $1 \mathrm{H}$ of $\mathrm{C}^{8} \mathrm{H}$ mentioned above), $6.20(\mathrm{br}, 2 \mathrm{H}, \mathrm{Ph}), 1.69$ (t, $J=7.2$ 
$\mathrm{Hz}, 2 \mathrm{H}, \mathrm{C}^{12} \mathrm{H}$ ), 1.29 (tt, apparent quint, $J=7.2,7.2 \mathrm{~Hz}, 2 \mathrm{H}$, $\left.\mathrm{C}^{11} \mathrm{H}\right), 0.05\left(\mathrm{t}, J=7.2 \mathrm{~Hz}, 2 \mathrm{H}, \mathrm{C}^{10} \mathrm{H}\right) ;{ }^{31} \mathrm{P}\left\{{ }^{1} \mathrm{H}\right\} \operatorname{NMR}(202.5$ $\left.\mathrm{MHz}, \mathrm{CD}_{2} \mathrm{Cl}_{2}\right) \delta$ : 10.29 (br, $\mathrm{CPPh}_{3}$ ), -16.05 (br, $\mathrm{OsPPh}_{3}$ ); ${ }^{13} \mathrm{C}\left\{{ }^{1} \mathrm{H}\right\}$ NMR $\left(125.8 \mathrm{MHz}, \mathrm{CD}_{2} \mathrm{Cl}_{2}\right.$, plus ${ }^{1} \mathrm{H}-{ }^{13} \mathrm{C} \mathrm{HMBC}$ and HSQC and ${ }^{13} \mathrm{C}$-dept 135) $\delta: 234.7\left(\mathrm{br}, \mathrm{C}^{1}\right), 189.0(\mathrm{~s}$, $\mathrm{C}^{5}$ ), 181.3 (br, $\mathrm{C}^{7}$ ), 177.2 (br, $\left.\mathrm{C}^{4}\right), 165.6\left(\mathrm{~s}, \mathrm{C}^{6}\right), 165.0$ [d, ${ }^{2} J(\mathrm{CP})=23.8 \mathrm{~Hz}, \mathrm{C}^{3}$ ], $157.9\left(\mathrm{br}, \mathrm{C}^{9}\right), 149.0\left(\mathrm{br}, \mathrm{C}^{8}\right), 134.5$ (br, $\mathrm{C}^{2}$ ), $146.7 \sim 125.2\left(\mathrm{Ph}\right.$, thiophene and $\mathrm{C}^{2}$ mentioned above), 122.0 (s, thiophene), $120.8\left[\mathrm{~d},{ }^{1} J(\mathrm{CP})=88.3 \mathrm{~Hz}\right.$, $\mathrm{Ph}$ ], 120.7 (s, thiophene), $34.3\left(\mathrm{~s}, \mathrm{C}^{10}\right), 28.9\left(\mathrm{~s}, \mathrm{C}^{11}\right), 23.0$ $\left(\mathrm{s}, \mathrm{C}^{12}\right.$ ); HRMS (ESI) calcd for $\mathrm{C}_{80} \mathrm{H}_{63} \mathrm{ClOsP}_{3} \mathrm{~S}_{2}[\mathrm{M}-$ $\mathrm{BF}_{4}^{-}$] 1407.2882, found 1407.2883. Anal. calcd for $\mathrm{C}_{80} \mathrm{H}_{63} \mathrm{BClF}_{4} \mathrm{OsP}_{3} \mathrm{~S}_{2}$ : C 64.32, $\mathrm{H} 4.25$; found $\mathrm{C} 64.46, \mathrm{H}$ 3.95 .

\subsubsection{Synthesis of complex 14}

A mixture of osmapentalyne $\mathbf{1 3}^{[13]}(200 \mathrm{mg}, 0.170$ $\mathrm{mmol})$ and 4-ethynylaniline $(59.7 \mathrm{mg}, 0.510 \mathrm{mmol})$ was stirred in DCM $(10 \mathrm{~mL})$ at room temperature for $2 \mathrm{~h}$ to give a green solution. The volume was reduced to about 2 $\mathrm{mL}$ under vacuum. Addition of $\mathrm{Et}_{2} \mathrm{O}(20 \mathrm{~mL})$ to the solution gave a grey precipitate, which was collected by filtration, washed with $\mathrm{Et}_{2} \mathrm{O}(10 \mathrm{~mL} \times 3)$, and dried under vacuum. The residue was purified by column chromatography (silica gel, eluent: $\mathrm{Me}_{2} \mathrm{CO}$ and $\mathrm{MeOH} / \mathrm{DCM}, V: V=1$ : $30)$ to give $110 \mathrm{mg}(50 \%$ yield $)$ of 14 as a green solid. ${ }^{1} \mathrm{H}$ NMR (600.1 MHz, $\left.\mathrm{CD}_{2} \mathrm{Cl}_{2}\right) \delta$ : $12.96\left(\mathrm{br}, 1 \mathrm{H}, \mathrm{C}^{1} \mathrm{H}\right), 7.27$ (br, $1 \mathrm{H}, \mathrm{C}^{8} \mathrm{H}$ ), $7.81 \sim 7.04$ (47H of $\mathrm{Ph}$ and $1 \mathrm{H}$ of $\mathrm{C}^{8} \mathrm{H}$ mentioned above), $6.84\left(\mathrm{~s}, 1 \mathrm{H}, \mathrm{C}^{3} \mathrm{H}\right), 6.23(\mathrm{br}, 2 \mathrm{H}, \mathrm{Ph}), 1.80(\mathrm{t}$, $\left.J=6.2 \mathrm{~Hz}, 2 \mathrm{H}, \mathrm{C}^{12} \mathrm{H}\right), 1.77 \sim 1.82\left(\mathrm{~m}, 2 \mathrm{H}, \mathrm{C}^{11} \mathrm{H}\right), 1.16(\mathrm{t}$, $\left.J=6.9 \mathrm{~Hz}, \quad 2 \mathrm{H}, \quad \mathrm{C}^{10} \mathrm{H}\right) ;{ }^{31} \mathrm{P}\left\{{ }^{1} \mathrm{H}\right\}$ NMR $(242.9 \mathrm{MHz}$, $\mathrm{CD}_{2} \mathrm{Cl}_{2}$ ) $\delta$ : 9.24 (br, $\mathrm{CPPh}_{3}$ ), - 15.88 (br, $\mathrm{OsPPh}_{3}$ ); ${ }^{13} \mathrm{C}\left\{{ }^{1} \mathrm{H}\right\}$ NMR (150.9 MHz, $\mathrm{CD}_{2} \mathrm{Cl}_{2}$, plus ${ }^{1} \mathrm{H}-{ }^{13} \mathrm{C} \mathrm{HMBC}$ and HSQC and ${ }^{13} \mathrm{C}$-dept 135) $\delta: 236.0\left(\mathrm{br}, \mathrm{C}^{1}\right), 188.2(\mathrm{~s}$, $\left.\mathrm{C}^{5}\right), 179.8\left[\mathrm{dt},{ }^{3} J(\mathrm{CP})=24.7 \mathrm{~Hz},{ }^{2} J(\mathrm{CP})=6.3 \mathrm{~Hz}, \mathrm{C}^{4}\right]$, $179.3\left[\mathrm{t},{ }^{2} J(\mathrm{CP})=7.0 \mathrm{~Hz}, \mathrm{C}^{7}\right], 171.2\left[\mathrm{t},{ }^{2} J(\mathrm{CP})=10.4 \mathrm{~Hz}\right.$, $\left.\mathrm{C}^{9}\right], 162.6\left(\mathrm{~s}, \mathrm{C}^{6}\right), 149.7\left[\mathrm{~d},{ }^{2} J(\mathrm{CP})=23.3 \mathrm{~Hz}, \mathrm{C}^{3}\right], 148.7$ $\left(\mathrm{s}, \mathrm{C}-\mathrm{NH}_{2}\right), 147.5\left[\mathrm{t},{ }^{3} J(\mathrm{CP})=4.7 \mathrm{~Hz}, \mathrm{C}^{8}\right], 135.5 \sim 125.6$ $(\mathrm{Ph}), 123.5\left[\mathrm{~d},{ }^{2} J(\mathrm{CP})=76.4 \mathrm{~Hz}, \mathrm{C}^{2}\right], 120.3\left[\mathrm{~d},{ }^{2} J(\mathrm{CP})=\right.$ $88.9 \mathrm{~Hz}, \mathrm{Ph}], 112.9(\mathrm{~s}, \mathrm{Ph}), 30.0\left(\mathrm{~s}, \mathrm{C}^{10}\right), 28.7\left(\mathrm{~s}, \mathrm{C}^{11}\right), 23.6$ $\left(\mathrm{s}, \mathrm{C}^{12}\right.$ ); HRMS (ESI) calcd for $\mathrm{C}_{72} \mathrm{H}_{60} \mathrm{ClNOsP}_{3}\left[\mathrm{M}-\mathrm{Cl}^{-}\right]$ 1258.3236, found 1258.3181. Anal calcd for $\mathrm{C}_{72} \mathrm{H}_{60} \mathrm{Cl}_{2} \mathrm{~N}-$ $\mathrm{OsP}_{3}$ : C 66.87, H 4.68, N 1.08; found C 67.17, H 4.50, N 1.16.

\subsubsection{Synthesis of complex $\mathbf{1 5}$}

A mixture of complex $7(200 \mathrm{mg}, 0.150 \mathrm{mmol})$ and hex-1-yne (36.9 mg, $0.450 \mathrm{mmol})$ was stirred in DCM (10 $\mathrm{mL}$ ) at room temperature for $4 \mathrm{~d}$ to give a green solution. The volume was reduced to about $2 \mathrm{~mL}$ under vacuum. Addition of $\mathrm{Et}_{2} \mathrm{O}(20 \mathrm{~mL})$ to the solution gave a grey precipitate, which was collected by filtration, washed with $\mathrm{Et}_{2} \mathrm{O}(10 \mathrm{~mL} \times 3)$, and dried under vacuum. The residue was purified by column chromatography (silica gel, eluent: $\mathrm{Me}_{2} \mathrm{CO}$ and $\left.\mathrm{MeOH} / \mathrm{DCM}, V: V=1: 30\right)$ to give $123 \mathrm{mg}$ $\left(58 \%\right.$ yield) of 15 as a green solid. ${ }^{1} \mathrm{H}$ NMR $(600.1 \mathrm{MHz}$, $\left.\mathrm{CD}_{2} \mathrm{Cl}_{2}\right) \delta: 13.74\left[\mathrm{~d},{ }^{3} J(\mathrm{HP})=19.7 \mathrm{~Hz}, 1 \mathrm{H}, \mathrm{C}^{1} \mathrm{H}\right], 7.31(\mathrm{~s}$, $1 \mathrm{H}, \mathrm{C}^{8} \mathrm{H}$, determined by ${ }^{1} \mathrm{H}_{-}{ }^{13} \mathrm{C}$ HSQC), $7.78 \sim 6.12(49 \mathrm{H}$ of $\mathrm{Ph}, 3 \mathrm{H}$ of thiophene groups, and $1 \mathrm{H}$ of $\mathrm{C}^{8} \mathrm{H}$ mentioned above), 1.96 (t, $\left.J=7.5 \mathrm{~Hz}, 2 \mathrm{H}, \mathrm{C}^{12} \mathrm{H}\right), 1.36$ (tt, apparent quint, $\left.J=7.5,7.5 \mathrm{~Hz}, 2 \mathrm{H}, \mathrm{C}^{11} \mathrm{H}\right), 0.73\left(\mathrm{~m}, 2 \mathrm{H}, \mathrm{C}^{15} \mathrm{H}\right), 0.61$ (br, $\left.5 \mathrm{H}, \mathrm{C}^{14} \mathrm{H} \& \mathrm{C}^{16} \mathrm{H}\right), 0.36\left(\mathrm{t}, J=6.8 \mathrm{~Hz}, 2 \mathrm{H}, \mathrm{C}^{13} \mathrm{H}\right), 0.00$ $\left(\mathrm{t}, J=7.5 \mathrm{~Hz}, 2 \mathrm{H}, \mathrm{C}^{10} \mathrm{H}\right) ;{ }^{31} \mathrm{P}\left\{{ }^{1} \mathrm{H}\right\}$ NMR $(242.9 \mathrm{MHz}$, $\left.\mathrm{CD}_{2} \mathrm{Cl}_{2}\right) \delta: 10.04\left(\mathrm{br}, \mathrm{CPPh}_{3}\right),-15.67\left[\mathrm{~d},{ }^{2} J(\mathrm{P}, \mathrm{P})=4.00\right.$ $\left.\mathrm{Hz}, \mathrm{OsPPh}_{3}\right] ;{ }^{13} \mathrm{C}\left\{{ }^{1} \mathrm{H}\right\}$ NMR $\left(150.9 \mathrm{MHz}, \mathrm{CD}_{2} \mathrm{Cl}_{2}\right.$, plus ${ }^{1} \mathrm{H}-{ }^{13} \mathrm{C}$ HMBC and HSQC and ${ }^{13} \mathrm{C}$-dept 135) $\delta$ : $236.0(\mathrm{br}$, $\left.\mathrm{C}^{1}\right), 189.7\left(\mathrm{~s}, \mathrm{C}^{5}\right), 185.4\left[\mathrm{t},{ }^{2} J(\mathrm{CP})=8.8 \mathrm{~Hz}, \mathrm{C}^{9}\right], 179.6[\mathrm{t}$, $\left.{ }^{2} J(\mathrm{CP})=7.0 \mathrm{~Hz}, \mathrm{C}^{7}\right], 177.0\left[\mathrm{dt},{ }^{3} J(\mathrm{CP})=24.1 \mathrm{~Hz},{ }^{2} J(\mathrm{CP})\right.$ $\left.=5.8 \mathrm{~Hz}, \mathrm{C}^{4}\right], 165.3\left[\mathrm{~d},{ }^{2} J(\mathrm{CP})=24.9 \mathrm{~Hz}, \mathrm{C}^{3}\right], 164.9(\mathrm{~s}$, $\left.\mathrm{C}^{6}\right), 149.8\left[\mathrm{t},{ }^{3} J(\mathrm{CP})=4.6 \mathrm{~Hz}, \mathrm{C}^{8}\right], 140.9$ ( $\mathrm{s}$, thiophene), 136.3 (s, thiophene), $134.7\left(\mathrm{br}, \mathrm{C}^{2}\right), 134.4 \sim 125.3(\mathrm{Ph}$, thiophene), $121.0\left[\mathrm{~d},{ }^{2} J(\mathrm{CP})=88.0 \mathrm{~Hz}, \mathrm{Ph}\right], 120.8$ (s, thiophene), $39.0\left(\mathrm{~s}, \mathrm{C}^{13}\right), 34.5\left(\mathrm{~s}, \mathrm{C}^{10}\right), 29.2\left(\mathrm{~s}, \mathrm{C}^{11}\right), 26.8(\mathrm{~s}$, $\left.\mathrm{C}^{14}\right), 23.5\left(\mathrm{~s}, \mathrm{C}^{12}\right), 22.2\left(\mathrm{~s}, \mathrm{C}^{15}\right), 13.8\left(\mathrm{~s}, \mathrm{C}^{16}\right)$; HRMS (ESI) calcd for $\mathrm{C}_{80} \mathrm{H}_{69} \mathrm{ClOsP}_{3} \mathrm{~S}\left[\mathrm{M}-\mathrm{Cl}^{-}\right]$1381.3631, found 1381.3640. Anal. calcd for $\mathrm{C}_{80} \mathrm{H}_{69} \mathrm{Cl}_{2} \mathrm{OsP}_{3} \mathrm{~S}$ : C 67.83, $\mathrm{H}$ 4.91; found C 67.94, H 4.83.

\subsection{Crystallographic analysis}

A crystal of 12 suitable for X-ray diffraction was grown from a DCE solution layered with hexane. Single-crystal X-ray diffraction data were collected on an Oxford Gemini S Ultra CCD Area Detector with graphite-monochromated $\mathrm{Cu} \mathrm{K} \alpha$ radiation $(\lambda=0.154184 \mathrm{~nm})$. The data were corrected for absorption effects using a multiscan technique. Using Olex2, ${ }^{[17]}$ the structure was solved by the Patterson function, completed by subsequent difference Fourier map calculations, and refined by a full-matrix least-squares method on $F^{2}$ using the SHELXTL program package. ${ }^{[18]}$ All of the non-hydrogen atoms were refined anisotropically unless otherwise stated. The hydrogen atoms were placed at their idealized positions and assumed the riding model unless otherwise stated. The solvent DCM $\left(\mathrm{CH}_{2} \mathrm{Cl}_{2}\right)$, methanol $\left(\mathrm{CH}_{3} \mathrm{OH}\right)$ and $\mathrm{H}_{2} \mathrm{O}$ molecule in 12 was refined without the addition of $\mathrm{H}$ atoms. X-ray crystal structure information is available at the Cambridge Crystallographic Data Centre (CCDC) under deposition numbers CCDC 1880246.

\subsection{DFT calculations}

All structures were optimized at the B3LYP level of DFT. ${ }^{[19]}$ Additionally, frequency calculations were also performed to identify all the stationary points as minima (zero imaginary frequency). In the B3LYP calculations, the effective core potentials (ECPs) of Hay and Wadt with a double- $\zeta$ valence basis set (LanL2DZ) $)^{[20]}$ were used to describe $\mathrm{Os}, \mathrm{S}, \mathrm{Cl}$ and $\mathrm{P}$ atoms, whereas the standard $6-31 \mathrm{G}$ basis set was used for C, O, N, F, B and $\mathrm{H}$ atoms. Polarization functions were added for Os $[\zeta(\mathrm{f})=0.886], \mathrm{S}[\zeta(\mathrm{d})=$ $0.421], \mathrm{Cl}[\zeta(\mathrm{d})=0.514]$, and $\mathrm{P}[\zeta(\mathrm{d})=0.340]^{[21]}$ in all calculations. All the optimizations were performed with the Gaussian 09 software package. ${ }^{[22]}$

Supporting Information Crystallographic data for complex 12 and spectroscopic data for all new compounds. 
Crystallographic structure of complex 12 (CCDC 1880246). Cartesian coordinates of the calculated structures $8 \sim 11$. The Supporting Information is available free of charge via the Internet at http://sioc-journal.cn.

\section{References}

[1] For reviews see: (a) Frogley, B. J.; Wright, L. J. Chem.-Eur. J. 2018, 24, 2025.

(b) Frogley, B. J.; Wright, L. J. Coord. Chem. Rev. 2014, 270, 151.

(c) Cao, X.; Zhao, Q.; Lin, Z.; Xia, H. Acc. Chem. Res. 2014, 47, 341.

(d) Zhu, C.; Cao, X.; Xia, H. Chin. J. Org. Chem. 2013, 33, 657 (in Chinese).

(朱从青, 曹晓宇, 夏海平, 有机化学, 2013, 33, 657.)

(e) Dalebrook, A. F.; Wright, L. J. Adv. Organomet. Chem. 2012, 60, 93.

(f) Paneque, M.; Poveda, M. L.; Rendón, N. Eur. J. Inorg. Chem. 2011, 1,19 .

(g) Bleeke, J. R. Acc. Chem. Res. 2007, 40, 1035

(h) Wright, L. J. Dalton Trans. 2006, 15, 1821.

(i) Landorf, C. W.; Haley, M. M. Angew. Chem., Int. Ed. 2006, 45, 3914.

(j) He, G.; Xia, H.; Jia, G. Chin. Sci. Bull. 2004, 49, 1543.

(k) Bleeke, J. R. Chem. Rev. 2001, 101, 1205.

(1) Bleeke, J. R. Acc. Chem. Res. 1991, 24, 271.

(m) Fernández, I.; Frenking, G.; Merino, G. Chem. Soc. Rev. 2015, 44, 6452.

(n) Feixas, F.; Matito, E.; Poater, J.; Solà, M. Chem. Soc. Rev. 2015, $44,6434$.

[2] See for examples: (a) Frogley, B. J.; Perera, L. C.; Wright, L. J. Chem.-Eur. J. 2018, 24, 4304.

(b) García-Rodeja, Y.; Fernández, I. Chem.-Eur. J. 2017, 23, 6634.

(c) Frogley, B. J.; Wright, L. J. Angew. Chem., Int. Ed. 2017, 56, 143.

(d) Huang, J.; Zhou, X.; Zhao, Q.; Li, S.; Xia, H. Chin. J. Chem. 2017, 35, 420

(e) Han, F.; Li, J.; Zhang, H.; Wang, T.; Lin, Z.; Xia, H. Chem.-Eur. J. 2015, 21, 565 .

(f) Lin, R.; Lee, K. H.; Sung, H. H. Y.; Williams, I. D.; Lin, Z.; Jia, G. Organometallics 2015, 34, 167.

(g) Vivancos, Á.; Hernández, Y.; Paneque, A. M.; Poveda, M. L.; Salazar, V.; Álvarez, E. Organometallics 2015, 34, 177.

(h) Han, F.; Wang, T.; Li, J.; Zhang, H.; Xia, H. Chem.-Eur. J. 2014, 20, 4363.

(i) Lin, R.; Lee, K.; Poon, K. C.; Sung, H. H. Y.; Williams, I. D.; Lin, Z.; Jia, G. Chem.-Eur. J. 2014, 20, 14885.

(j) Vivancos, Á.; Paneque, M.; Poveda, M. L.; Álvarez, E. Angew. Chem., Int. Ed. 2013, 52, 10068.

(k) Wang, T.; Zhang, H.; Han, F.; Long, L.; Lin, Z.; Xia, H. Chem.-Eur. J. 2013, 19, 10982.

(1) Wang, T.; Zhang, H.; Han, F.; Long, L.; Lin, Z.; Xia, H. Angew. Chem., Int. Ed. 2013, 52, 9251.

(m) Poon, K. C.; Liu, L.; Guo, T.; Li, J.; Sung, H. H. Y.; Williams, I. D.; Lin, Z.; Jia, G. Angew. Chem., Int. Ed. 2010, 49, 2759.

(n) Clark, G. R.; Ferguson, L. A.; Mclntosh, A. E.; Sohnel, T.; Wright, L. J. J. Am. Chem. Soc. 2010, 132, 13443.

(o) Paneque, M.; Posadas, C. M.; Poveda, M. L.; Rendón, N.; Salazar, V.; Oñate, E.; Mereiter, K. J. Am. Chem. Soc. 2003, 125, 9898.

(p) Jacob, V.; Weakley, T. J. R.; Haley, M. M. Angew. Chem., Int. Ed. 2002, 41, 3470.

(q) Gilbertson, R. D.; Weakley, T. J. R.; Haley, M. M. Chem.-Eur. J. 2000, 6, 437.

(r) Gilbertson, R. D.; Weakley, T. J. R.; Haley, M. M. J. Am. Chem. Soc. 1999, 121, 2597.

(s) Elliott, G. P.; Roper, W. R.; Waters, J. M. J. Chem. Soc., Chem. Commun. 1982, 0, 811 .
[3] For reviews see: (a) Jia, G. Organometallics 2013, 32, 6852. (b) Chen, J.; He, G.; Jia, G. Chin. J. Org. Chem. 2013, 33, 792 (in Chinese).

(陈江溪, 何国梅, 贾国成, 有机化学, 2013, 33, 792.)

(c) Chen, J.; Jia, G. Coord. Chem. Rev. 2013, 257, 2491.

(d) Jia, G. Coord. Chem. Rev. 2007, 251, 2167.

(e) Jia, G. Acc. Chem. Res. 2004, 37, 479.

[4] See for examples: (a) Ruan, W.; Leung, T.-F.; Shi, C.; Lee, K. H.; Sung, H. H. Y.; Williams, I. D.; Lin, Z.; Jia, G. Chem. Sci. 2018, 9, 5994.

(b) Wen, T. B.; Lee, K.-H.; Chen, J.; Hung, W. Y.; Bai, W.; Li, H.; Sung, H. H. Y.; Williams, I. D.; Lin, Z.; Jia, G. Organometallics 2016, 35, 1514.

(c) Chen, J.; Lee, K.-H.; Wen, T. B.; Gao, F.; Sung, H. H. Y.; Williams, I. D.; Lin, Z.; Jia, G. Organometallics 2015, 34, 890.

(d) Chen, J.; Shi, C.; Sung, H. H. Y.; Williams, I. D.; Lin, Z.; Jia, G. Chem.-Eur. J. 2012, 18, 14128.

(e) Chen, J.; Sung, H. H. Y.; Williams, I. D.; Lin, Z.; Jia, G. Angew. Chem., Int. Ed. 2011, 50, 10675.

(f) Hung, W. Y.; Liu, B.; Shou, W.; Wen, T. B.; Shi, C.; Sung, H. H. Y.; Williams, I. D.; Lin, Z.; Jia, G. J. Am. Chem. Soc. 2011, 133, 18350 .

(g) Liu, B.; Xie, H.; Wang, H.; Wu, L.; Zhao, Q.; Chen, J.; Wen, T. B.; Cao, Z.; Xia, H. Angew. Chem., Int. Ed. 2009, 48, 5461.

(h) He, G.; Zhu, J.; Hung, W. Y.; Wen, T. B.; Sung, H. H. Y.; Williams, I. D.; Lin, Z.; Jia, G. Angew. Chem., Int. Ed. 2007, 46, 9065.

(i) Wen, T. B.; Hung, W. Y.; Sung, H. H. Y.; Williams, I. D.; Jia, G. J. Am. Chem. Soc. 2005, 127, 2856.

(j) Wen, T. B.; Ng, S. M.; Hung, W. Y.; Zhou, Z. Y.; Lo, M. F.; Shek, L.-Y.; Williams, I. D.; Lin, Z.; Jia, G. J. Am. Chem. Soc. 2003, 125,884 .

(k) Wen, T. B.; Zhou, Z. Y.; Jia, G. Angew. Chem., Int. Ed. 2001, 40, 1951.

[5] (a) Wei, J.; Zhang, Y.; Chi, Y.; Liu, L.; Zhang, W. X.; Xi, Z. J. Am. Chem. Soc. 2016, $138,60$.

(b) Aztatzi, R. G.; Mercero, J. M.; Matito, E.; Frenking, G.; Ugalde, J. M. Phys. Chem. Chem. Phys. 2017, 19, 9669.

(c) An, K.; Shen, T.; Zhu, J. Organometallics 2017, 36, 3199.

(d) Chen, J.; Lee, K.-H.; Sung, H. H. Y.; Williams, I. D.; Lin, Z.; Jia, G. Angew. Chem., Int. Ed. 2016, 55, 7194.

(e) Wei, J.; Zhang, W.; Xi, Z. Chem. Sci. 2018, 9, 560.

(f) Ma, W.; Yu, C.; Chi, Y.; Chen, T.; Wang, L.; Yin, J.; Wei, B.; Xu, L.; Zhang, W.; Xi, Z. Chem. Sci. 2017, 8, 6852.

(g) Ma, W.; Yu, C.; Chen, T.; Xu, L.; Zhang, W.; Xi, Z. Chem. Soc. Rev. 2017, 46, 1160 .

(h) Wei, J.; Zhang, W.; Xi, Z. Angew. Chem., Int. Ed. 2015, 54, 5999.

(i) Wei, J.; Zhang, Y.; Zhang, W.; Xi, Z. Angew. Chem., Int. Ed. 2015, 54, 9986.

(j) Wang, H.; Zhou, X.; Xia, H. Chin. J. Chem. 2018, 36, 93.

(k) Zheng, S.; Chu, Z.; Lee, K.-H.; Lin, Q.; Li, Y.; He, G.; Chen, J.; Jia, G. ChemPlusChem 2019, 84, 85 .

[6] (a) Hua, Y.; Lan, Q.; Fei, J.; Tang, C.; Lin, J.; Zha, H.; Chen, S.; Lu, Y.; Chen, J.; He, X.; Xia. H. Chem.-Eur. J. 2018, 24, 14531.

(b) Zhou, X.; Li, Y.; Shao, Y.; Hua, Y.; Zhang, H.; Lin, Y.; Xia, H. Organometallics 2018, 37, 1788.

(c) Li, J.; Kang, H.; Zhuo, K.; Zhuo, Q.; Zhang, H.; Lin, Y.-M.; Xia, H. Chin. J. Chem. 2018, 36, 1156.

(d) Mauksch, M.; Tsogoeva, B. S. Chem.-Eur. J. 2010, 16, 7843.

(f) Chen, J.; Lin, Q.; Li, S.; Lu, Z.; Lin, J.; Chen, Z.; Xia, H. Organometallics 2018, 37, 618 .

(g) Zhou, X.; Wu, J.; Hao, Y.; Zhu, C.; Zhuo, Q.; Xia, H.; Zhu, J. Chem.-Eur. J. 2018, 24, 2389.

(h) Zhu, C.; Zhu, J.; Zhou, X.; Zhu, Q.; Yang, Y.; Wen, T. B.; Xia, H. Angew. Chem., Int. Ed. 2018, 57, 3154.

(i) Lu, Z.; Zhu, C.; Cai, Y.; Zhu, J.; Hua, Y.; Chen, Z.; Chen, J.; Xia, H. Chem.-Eur. J. 2017, 23, 6426.

(j) Zhu, C.; Zhu, Q.; Fan, J.; Zhu, J.; He, X.; Cao, X. Y.; Xia, H. 
Angew. Chem., Int. Ed. 2014, 53, 6232.

(k) Luo, M.; Long, L.; Zhang, H.; Yang, Y.; Hua, Y.; Liu, G.; Lin, Z.; Xia, H. J. Am. Chem. Soc. 2017, 159, 1822

(1) Zhu, C.; Wu, J.; Li, S.; Yang, Y.; Zhu, J.; Lu, X.; Xia, H. Angew. Chem., Int. Ed. 2017, 56, 9067.

(m) Zhu, Q.; Zhu, C.; Deng, Z.; He, G.; Chen, J.; Zhu, J.; Xia, H. Chin. J. Chem. 2017, 35, 628.

(n) Luo, M.; Zhu, C.; Chen, L.; Zhang, H.; Xia, H. Chem. Sci. 2016, 7,1815 .

(o) Zhu, C.; Zhou, X.; Xing, H.; An, K.; Zhu, J.; Xia, H. Angew. Chem., Int. Ed. 2015, 54, 3102.

(p) Zhu, C.; Yang, Y.; Wu, J.; Luo, M.; Fan, J.; Zhu, J.; Xia, H. Angew. Chem., Int. Ed. 2015, 54, 7189 .

(q) Zhu, C.; Luo, M.; Zhu, Q.; Zhu, J.; Schleyer, P. v. R.; Wu, J.

I.-C.; Lu, X.; Xia, H. Nat. Commun. 2014, 5, 3265.

(r) Hua, Y.; Zhang, H.; Xia, H. Chin. J. Org. Chem. 2018, 38, 11 (in Chinese).

(华显晖, 张弘, 夏海平, 有机化学, 2018, 38, 11.)

(s) Zhu, C.; Xia, H. Acc. Chem. Res. 2018, 51, 1691.

(t) Lu, Z.; Chen, J.; Xia, H. Chin. J. Org. Chem. 2017, 37, 1181 (in Chinese).

(路正宇, 陈江溪, 夏海平, 有机化学, 2017, 37, 1181.)

[7] (a) Zhou, X.; Wu, J.; Hao, Y.; Zhu, C.; Zhuo, Q.; Xia, H.; Zhu, J. Chem.-Eur. J. 2018, 24, 2296.

(b) Ritter, S. K. C\&EN 2016, 94, 9.

(c) Xia, H. Chin. J. Chem. 2018, 36, 78

[8] Zhu, C.; Li, S.; Luo, M.; Zhou, X.; Niu, Y.; Lin, M.; Zhu, J.; Cao, Z.; Lu, X.; Wen, T.; Xie, Z.; Schleyer, P. V. R.; Xia, H. Nat. Chem. 2013, 5, 698 .

[9] Li, R.; Lu, Z.; Cai, Y.; Jiang, F.; Tang, C.; Chen, Z.; Zheng, J.; Pi, J.; Zhang, R.; Liu, J.; Chen, Z.-B.; Yang, Y.; Shi, J.; Hong, W.; Xia, H. J. Am. Chem. Soc. 2017, 139, 14344.

[10] (a) Zhu, C.; Yang, Y.; Luo, M.; Yang, C.; Wu, J.; Chen, L.; Liu, G.; Wen, T. B.; Zhu, J.; Xia, H. Angew. Chem., Int. Ed. 2015, 54, 6181. (b) Lu, Z.; Lin, Q.; Cai, Y.; Chen, S.; Chen, J.; Wu, W.; He, X.; Xia, H. ACS Macro Lett. 2018, 7, 1034.

(c) Lu, Z.; Cai, Y.; Wei, Y.; Lin, Q.; Chen, J.; He, X.; Li, S.; Wu, W.; Xia, H. Polym. Chem. 2018, 9, 2092.

(d) Lin, Q.; Li, S.; Lin, J.; Chen, M.; Lu, Z.; Tang, C.; Chen, Z.; He, X.; Chen, J.; Chem.-Eur. J. 2018, 24, 8375.

(e) He, X.; He, X.; Li, S.; Zhuo, K.; Qin, W.; Dong, S.; Chen, J.; Ren, L.; Liu, G.; Xia, H. Polym. Chem. 2017, 8, 3674.

[11] (a) Yang, C.; Lin, G.; Zhu, C.; Pang, X.; Zhang, Y.; Wang, X.; Li, X.; Wang, B.; Xia, H.; Liu, G. J. Mater. Chem. B 2018, 6, 2528.

(b) Zhu, C.; Yang, C.; Wang, Y.; Lin, G.; Yang, Y.; Wang, X.; Zhu, J.; Chen, X.; Lu, X.; Liu, G.; Xia, H. Sci. Adv. 2016, 2, e1601031.

[12] Li, N.; Zhao, P.; Astruc, D. Angew. Chem., Int. Ed. 2014, 53, 1756.

[13] Zhuo, Q.; Lin, J.; Hua, Y.; Zhou, X.; Shao, Y.; Chen, S.; Chen, Z.;
Zhu, J.; Zhang, H.; Xia, H. Nat. Commun. 2017, 8, 1912.

[14] Zhuo, Q.; Zhang, H.; Hua, Y.; Kang, H.; Zhou, X.; Lin, X.; Chen, Z.; Lin, J.; Zhuo, K.; Xia, H. Sci. Adv. 2018, 4, eaat0336.

[15] Weissleder, R. Nat. Biotechnol. 2001, 19, 316.

[16] For reviews see: (a) Snook, R. Chem. Soc. Rev. 1997, 26, 319.

(b) Sau, T. K.; Rogach, A. L.; Jackel, F.; Klar, T. A.; Feldmann, J. Adv. Mater. 2010, 22, 1805.

(c) Dreaden, E. C.; Mackey, M. A.; Huang, X.; Kang, B.; El-Sayed, M. A. Chem. Soc. Rev. 2011, 40, 3391.

(d) Ray, P. C.; Khan, S. A.; Singh, A. K.; Senapati, D.; Fan, Z. Chem. Soc. Rev. 2012, 41, 3193.

(e) Zhang, Z.; Wang, J.; Chen, C. Adv. Mater. 2013, 25, 3869.

(f) Habault, D.; Zhang, H.; Zhao, Y. Chem. Soc. Rev. 2014, 42, 7244.

(g) Shanmugam, V.; Selvakumar, S.; Yeh, C.-S. Chem. Soc. Rev. 2014, 43, 6254 .

(h) Ng, K. K.; Zheng, G. Chem. Rev. 2015, 115, 11012.

(i) Dumas, A.; Couvreur, P. Chem. Sci. 2015, 6, 2153.

(j) Lan, G.; Ni, K.; Lin, W. Coord. Chem. Rev. 2019, 379, 65.

[17] Dolomanov, O. V.; Bourhis, L. J.; Gildea, R. J.; Howard, J. A. K.; Puschmann, H. J. Appl. Crystallogr. 2009, 42, 339.

[18] Sheldrick, G. M. Acta Crystallogr., Sect. A 2015, 71, 3.

[19] (a) Becke, A. D. J. Chem. Phys. 1993, 98, 5648.

(b) Miehlich, B.; Savin, A.; Stoll, H.; Preuss, H. Chem. Phys. Lett. 1989, 157, 200.

(c) Lee, C.; Yang, W.; Parr, R. G. Phys. Rev. B 1988, 37, 785.

[20] Hay, P. J.; Wadt, W. R. J. Chem. Phys. 1985, 82, 299.

[21] Huzinaga, S.; Andzelm, J.; Radzio-Andzelm, E.; Sakai, Y.; Tatewaki, H.; Klobukowski, M. Gaussian Basis Sets for Molecular Calculations, Elsevier Science, Amsterdam, 1984

[22] Frisch, M. J.; Trucks, G. W.; Schlegel, H. B.; Scuseria, G. E.; Robb, M. A.; Cheeseman, J. R.; Scalmani, G.; Barone, V.; Mennucci, B.; Petersson, G. A.; Nakatsuji, H.; Caricato, M.; Li, X.; Hratchian, H. P.; Izmaylov, A. F.; Bloino, J.; Zheng, G.; Sonnenberg, J. L.; Hada, M.; Ehara, M.; Toyota, K.; Fukuda, R.; Hasegawa, J.; Ishida, M.; Nakajima, T.; Honda, Y.; Kitao, O.; Nakai, H.; Vreven, T.; Montgomery, J. A., Jr.; Peralta, J. E.; Ogliaro, F.; Bearpark, M.; Heyd, J. J.; Brothers, E.; Kudin, K. N.; Staroverov, V. N.; Kobayashi, R.; Normand, J.; Raghavachari, K.; Rendell, A.; Burant, J. C.; Iyengar, S. S.; Tomasi, J.; Cossi, M.; Rega, N.; Millam, J. M.; Klene, M.; Knox, J. E.; Cross, J. B.; Bakken, V.; Adamo, C.; Jaramillo, J.; Gomperts, R.; Stratmann, R. E.; Yazyev, O.; Austin, A. J.; Cammi, R.; Pomelli, C.; Ochterski, J. W.; Martin, R. L.; Morokuma, K.; Zakrzewski, V. G.; Voth, G. A.; Salvador, P.; Dannenberg, J. J.; Dapprich, S.; Daniels, A. D.; Farkas, O.; Foresman, J. B.; Ortiz, J. V.; Cioslowski, J.; Fox, D. J. Gaussian 09, revision D. 01, Gaussian, Inc., Wallingford, CT, 2009. 